\title{
Does Birthplace Diversity Affect Economic Complexity? Cross-country Evidence
}

Dany Bahar, Hillel Rapoport and

Riccardo Turati

CID Research Fellow and Graduate Student

Working Paper No. 125

March 2020

(c) Copyright 2020 Bahar, Dany; Rapoport, Hillel; Turati, Riccardo; and the President and Fellows of Harvard College



\title{
Does Birthplace Diversity affect Economic Complexity? Cross-country Evidence*
}

\author{
Dany Bahar ${ }^{\mathrm{a}}$, Hillel Rapoport ${ }^{\mathrm{b}}$, and Riccardo Turati $^{\mathrm{c}}$ \\ ${ }^{\mathrm{a}}$ The Brookings Institution, Harvard CID, CESifo and IZA \\ ${ }^{\mathrm{b}}$ Paris School of Economics, Université Paris 1 Panthéon-Sorbonne and CEPII \\ ${ }^{\mathrm{c}}$ IRES/LIDAM, UCLouvain
}

March 2020

\begin{abstract}
We empirically investigate the relationship between a country's economic complexity and the diversity in the birthplaces of its immigrants. Our cross-country analysis suggests that countries with higher birthplace diversity by one standard deviation are more economically complex by 0.1 to 0.18 standard deviations above the mean. This holds particularly for diversity among highly educated migrants and for countries at intermediate levels of economic complexity. We address endogeneity concerns by instrumenting diversity through predicted stocks from a pseudo-gravity model as well as from a standard shift-share approach. Finally, we provide evidence suggesting that birthplace diversity boosts economic complexity by increasing the diversification of the host country's export basket.
\end{abstract}

Keywords: economic complexity, birthplace diversity, immigration, growth.

JEL codes: F22, O31, O33

*The usual disclaimer applies. Addresses: Dany Bahar, dbahar@brookings.edu, The Brookings Institution, 1775 Massachusetts Ave NW Washington DC 20001, USA; Hillel Rapoport, hillel.rapoport@psemail.eu, PSE, 48 Boulevard Jourdan, 75014 Paris, France; Riccardo Turati, r.turati@uclouvain.be, UCLouvain, Place Montesquieu, 3 - 01348 Louvain-la-Neuve, Belgium. Hillel Rapoport acknowledges support from Agence Nationale de la Recherche under the framework of the Investissements d'avenir program (ANR-17-EURE-001). 


\section{Introduction}

Diversity of immigration (or immigrants' birthplace diversity) has been shown to boost economic performance at different levels of aggregation: countries (e.g., Ortega and Peri, 2014, Alesina et al., 2016, Bove and Elia, 2016), regions (e.g., Trax et al., 2015), US metropolitan areas, counties and states (e.g., Ottaviano and Peri, 2006, Ager and Brückner, 2013, Fulford et al., 2017; Docquier et al., 2019), or firms (e.g., Parrotta et al. 2014 Trax et al. 2015) 1 The dominant interpretation for the positive association between birthplace diversity and economic performance has to do with the complementarity in skills and knowledge sets brought about by immigrants who grew up in different environments, went to different school systems, and learned different trades and skills as a result. As immigrants expand the set of skills a country can access to, by the same token they also expand its opportunities to become competitive in a broader set of economic activities. Social scientists have recently proposed to measure the extent to which an economy is capable of becoming competitive in a more diverse set of industries by quantifying its "economic complexity" (e.g., Hausmann and Klinger, 2007, Hidalgo et al., 2007, Hidalgo and Hausmann, 2009). This paper empirically explores the relationship between a country's population birthplace diversity and its levels of economic complexity.

During the last decades, virtually all modern economies have become more demographically diverse. While the global share of immigrants has remained stable over time -at about three percent of the world population- the share of the foreign-born population in OECD countries has increased from seven to thirteen percent on average between 1970 and 2010. Some countries have experienced a dramatic growth of the share of foreign born over the 1970-2010 period. For example, Spain (from 1.1 to 15 percent), Greece (from 1 to 10 percent), and Portugal (from 1 to 9 percent) $2^{2}$ Moreover, the composition of the foreign-born population in OECD countries has changed mostly due to immigration from developing countries, with the average share of non-OECD migrants growing by a factor of 8.7 over the 1970-2010 period against just 1.2 for OECD migrants over the same period.

Our focus on economic complexity is based on the findings of a burgeoning literature which has documented how more complex economies tend to enjoy higher levels of income and better growth prospects (e.g., Hidalgo and Hausmann, 2009, Hausmann et al., 2014). Exploring the different ways through which countries achieve higher complexity, however, is still an open question. A common interpretation of the drivers of economic complexity is the availability of accumulated unobserved capabilities, or productive know-how, which in turn is reflected in the composition of a country's export basket, namely its level of diversification and its uniqueness. Achieving an export basket that is more diversified and includes less ubiquitous products (and, hence, generates higher growth prospects), conceptually, would imply drawing from a more diverse set of complementary skills in the economy. Following this line of thought, we investigate whether economic

\footnotetext{
${ }^{1}$ At very low levels of aggregation such as teams, there are many instances of negative outcomes, especially when focusing on ethnic diversity in contexts of conflict (e.g., Hjort, 2014, Lyons 2017). In this paper we focus on birthplace diversity, rather than other measures of diversity used in the literature, such as ethnic (e.g., Alesina and La Ferrara. 2005) or linguistic (e.g., Desmet et al. 2012) diversity.

${ }^{2}$ The OECD countries with the highest share of foreign-born in 2010 are Israel (36 percent), Luxembourg (33 percent), Australia (25 percent) and Canada (21 percent), according to the World Bank's Bilateral Migration Database (available here).
} 
complexity is positively affected by higher birthplace diversity of the local labor force. In essence, the more diverse a country is in terms of its population's birthplaces, the more accumulated knowledge there is in terms of idiosyncratic individual characteristics to draw from. As long as these characteristics and skills are complementary one to the other (and to the native set of skills and knowledge), they should translate into higher levels of economic complexity, income per capita, and economic growth.

In this paper, we put these ideas to the test. In particular, we gather data on bilateral migration stocks between countries to construct measures of immigration diversity and investigate how these relate to measures of economic complexity (i.e., to the "Economic Complexity Index" of Hidalgo and Hausmann (2009) and Hausmann and Hidalgo (2011)). Our baseline regressions use the Herfindahl index of diversity (a measure of the likelihood that two randomly drawn immigrants are from different countries), however in our robustness analysis we use alternative measures of diversity such as the Theil index and its components, finding consistent results. We go beyond Alesina et al. (2016) as we look at a potential driver behind their results, showing that birthplace diversity affects complexity which in turns affects growth. Moreover, since economic complexity (as measured in Hidalgo and Hausmann (2009)) is a combination of countries' export diversification and abilities to produce less ubiquitous products, we estimate the relationship between birthplace diversity on these two components of complexity, thus shedding light on the mechanisms through which diversity ultimately affects economic growth.

We find that, on average, countries with one standard deviation from our sample mean in terms of birthplace diversity exhibit higher levels of economic complexity by 0.1 to 0.18 standard deviations above the mean. These results are particularly strong when limiting our birthplace diversity measure to skilled migrants (i.e., to migrants with college education or more), consistently with the idea that the relationship between diversity and complexity is driven by skill-complementarity. Furthermore our results are particularly strong among developing countries that are in the middle of the economic complexity distribution, suggesting that an increase in skill variety is particularly relevant for boosting countries development path. We also find that our results are particularly strong for inflows of immigrants from origin countries with little to no prior immigration in the host country of interest. We further show that our results are robust to using the Theil index of diversity and its decomposition into a "between" and a "within" component. In particular, we find that most of the effect is driven by the "between" component, which can be interpreted as the extensive margin of diversity in the sense that it captures the contribution of new origin countries to the evolution of immigration diversity. This is consistent with our interpretation that the relation between diversity and complexity is fundamentally about expanding the set of skills and knowledge to be combined in production.

Our results are robust to controlling for potential omitted factors related to immigration diversity such as transfers of technological norms from origin to destination countries with an origin-specific effect (e.g., Valette, 2018), or to controlling for birthplace diversity of immigrants in 1960 (thereby ruling out the possibility that the results are driven by the diversity of the second and third generations of immigrants). Our results are also robust to controlling for the baseline levels of countries' income and export baskets diversification. Finally, 
we are able to rule out our results being driven by time-invariant unobserved heterogeneity.

In an attempt to go beyond correlation and deal with endogeneity concerns, we propose two instrumental variable approaches. The first is based on the prediction of skill-specific bilateral stocks of immigrants through a gravity model (see Alesina et al. (2016) and Docquier et al. (2019)). Including a set of common gravity controls from the trade literature (such as distance, common language, sharing borders, etc.) and interactions between origin and year dummies to capture all the push-time variant factors, we then predict skill-specific bilateral stocks. With those predicted stocks we built our first set of instrumental variables, as skill-specific predicted birthplace diversity indexes. The second approach is based on the shift-share instrument (Card (2001) and Moriconi et al. (2018)) to predict the skill-specific bilateral immigration stocks based on the location of immigrants by origin countries in the 1970s and the aggregate skill-specific flows from origin countries. The predicted stocks are then determined by preexisting networks of immigrants and not by recent economic/social factors. Therefore, we argue, our instruments based on this methodology are less prone to reverse causation bias. Moreover, since important historical and migration specific events happened which are orthogonal to the cross-country distribution of immigrants in the 1970s and produced exogenous variation of migration flows ${ }^{3}$ the 1970 distribution of immigrants can reasonably be less correlated with countryspecific persisting factors that affect future dynamics in economic complexity. Those exogenous shocks were indeed large and strengthen the reliability of our approach, since the correlation between our instrument and unobserved persistent country-specific factors is mitigated. Combining both approaches (gravity model and shift-share based instruments), our estimates support a causal interpretation for the effect of diversity on economic complexity, in particular among developing countries.

The rest of the paper is organized as follows. Section 2 discusses the data sources and presents some stylized facts on the evolution and distribution of both economic complexity and of birthplace diversity. Section 3 presents our empirical approach and our strategies to deal with endogeneity. Section 4 shows the main results of the analysis. In Section 5 we discuss the robustness of our results. Section 6 discusses candidate mechanisms. Finally, Section 7 concludes.

\section{Data and Stylized Facts}

Our paper investigates the relationship between the birthplace diversity of immigrants and the level of economic complexity of the host countries. Combining different sources, our main analysis covers a sample of 100 countries over the period 1990 to 2000. In Section 2.1 we describe our data on skill-specific immigration and various measures of birthplace diversity, and in Section 2.2 we describe the measures of economic complexity used. As a preamble to our econometric estimation, we present in Section 2.3 some stylized facts that include suggestive evidence of a positive relationship between birthplace diversity and complexity.

\footnotetext{
${ }^{3}$ Some examples are the fall of the Soviet Union and the resulting opening of the Iron Curtain in 1989, the creation of the European Union and of the Schengen Area that allowed free movement of Europeans in 1995 and the recent implementation of the Hart-Cellar Act which changed the quota system in the US and became effective at the end of 1968 .
} 


\subsection{Immigration and Diversity Indexes}

Our data source on migration stocks comes from Artuc et al. (2015) (henceforth ADOP (2015)). This dataset provides a square matrix of bilateral migration stocks for 195 countries for the years 1990 and 2000. It also contains migration stocks disaggregated by education level of migrants, splitting them between college and non-college educated, as well as disaggregated by gender. In the dataset, an immigrant is defined as a 25 year or older foreign-born individual. Due to the high coverage of destination and origin countries and the skill composition of the stocks, this data set is increasingly used in cross-country analysis (e.g., Docquier et al., 2015, Alesina et al. 2016, Bahar and Rapoport, 2018). In keeping with the literature on birthplace diversity reviewed in the introduction and following the decomposition of birthplace diversity over the total population suggested by Alesina et al. (2016), we compute a country-level fractionalization index based on the immigrant population by skill group ${ }^{4}$ Namely, given destination country $d$, origin country $o \in O=\{1, \ldots, 195\}$ and year $t$, our immigrant birthplace diversity index is:

$$
D i v_{d, t, s}^{M i g}=\sum_{o}^{O} \bar{m}_{d, o, t, s}\left(1-\bar{m}_{d, o, t, s}\right)
$$

where $\bar{m}_{d, o, t, s}$ is the stock of immigrants from country of origin $o$ in destination country $d$ at year $t$ with education $s \in E=\{A l l, H S, L S\}$ over the total stock of immigrants in country $d$ with the same education level. Thanks to the decomposition of the fractionalization index and including simultaneously in our empirical strategy both the immigration birthplace diversity index and the immigration share allows us to control for the size and composition of the immigrant population. Moreover, as pointed out in Alesina et al. (2016), the correlation between the immigration share and the birthplace diversity index computed for the total country population (rather then for the immigrant population) is extremely high and close to one (in our sample it is 0.981$)$.

By construction, our immigrant birthplace diversity index is between 0 and 1 . It measures the probability to draw randomly two individuals from the immigrant population that are born in different countries. A higher value for the index implies a more diverse immigrant population. To simplify further analysis, we standardize our measure of diversity with mean 0 and standard deviation equal to 1 . Figure 1 plots the standardized level of birthplace diversity across countries. As can be seen, the birthplace diversity of immigrants can be quite high in countries with large foreign-born populations (e.g., in Western countries) or in countries where the share of foreign-born is small (e.g., China). In fact, there is little correlation between the share of immigrants in the host-country population and their diversity (see Alesina et al. (2016)).

Computing a skill-specific fractionalization index over the immigrants population is not the only way to measure countries' diversity. An alternative approach is to measure countries polarization rather than diversity. The intuition is that a more polarized population can be associated with a reduction of social

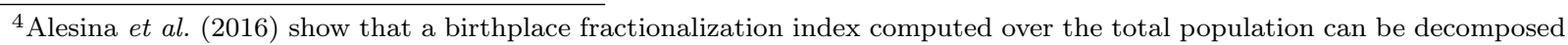
in two components: the between component, which captures the diversity driven by the fraction of foreing-born, and the within component, which captures the additional diversity brought about by the fact that the foreign-born are born in different countries.
} 
Figure 1: Birthplace Migration Diversity 2000

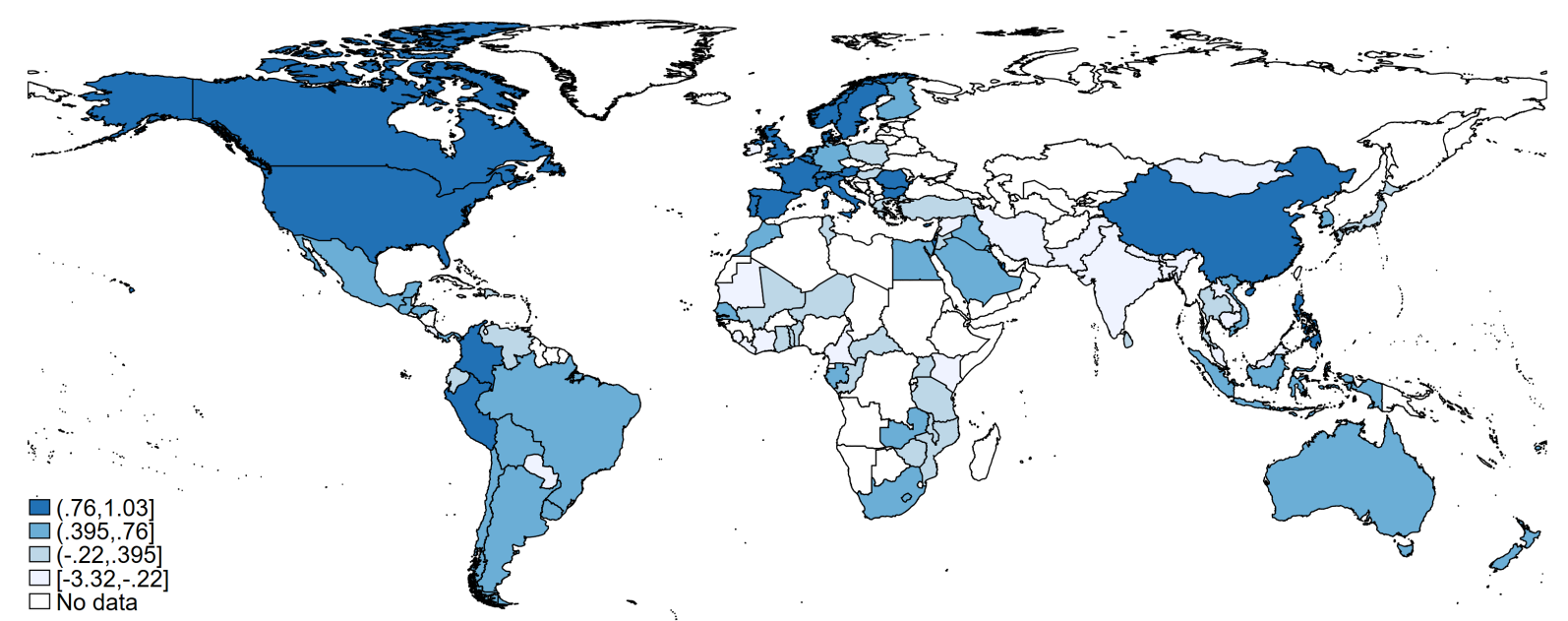

Note: authors' calculations on ADOP 2015 data. The map plots the standardized value of the birthplace diversity index on the overall population of migrants in year 2000.

cohesion and public good provision. Since the highest level of polarization is associated with a population characterized by two groups of equal size, a highly polarized society implies less diversity and, hence, a less diverse set of skills and competences. Following Montalvo and Reynal-Querol (2005) and Ager and Brückner (2013) we compute a skill-specific polarization index over the immigrants population which captures how far the population distribution is from a bimodal distribution, which is written:

$$
\operatorname{Pol}_{d, t, s}^{M i g}=1-\sum_{o}^{O}\left(\frac{0.5-\bar{m}_{d, o, t, s}}{0.5}\right)^{2} \bar{m}_{d, o, t, s}
$$

Since we compute it over the immigrant population, this index reaches its maximum level when a country's immigrant population is composed by two groups of equal size. Table B-1 shows that skill-specific fractionalization and polarization are negatively correlated. Moreover, if our prior is that the positive relation between population diversity and economic complexity is driven by the expansion of the set of skills and competences brought by different immigrants, we should find a negative relation between the birthplace polarization index and economic complexity. We will test this hypothesis.

Another alternative index of population diversity is the Theil index. Adopted in the trade literature (e.g., Cadot et al. 2013), such index is used to compute measures of export diversification using as inputs a vector of a country's per-product export shares. We can apply this index, too, to measure diversity by computing a skill-specific Theil index over the immigrant population as follow:

$$
\operatorname{Theil}_{d, t, s}^{M i g}=\frac{1}{N} \sum_{o}^{O}\left(\frac{M I G_{d, o, t, s}}{\mu_{d, t, s}}\right) \ln \left(\frac{M I G_{d, o, t, s}}{\mu_{d, t, s}}\right)
$$

where $M I G_{d, o, t, s}$ is the total stock of immigrants from origin country $o$ in destination country $d$ at year $t$ with education $s$. The number of immigrants countries of origin is represented by $N=195$, while $\mu_{d, t, s}$ is 
the average skill-specific size of the immigrant groups 5 Compared to our benchmark fractionalization index computed in equation (1), the Theil index has two substantial differences. First, the Theil index is equal to zero when we have perfect diversification within the immigrants population, implying that immigrants are perfectly distributed among countries of origin. For this reason the Theil index is negatively related with our fractionalization index, as Table B-1 shows. Second, the Theil index can be decomposed along two dimensions, allowing for a better understanding of the relation between diversity and economic complexity. Following Cadot et al. (2011), we decompose the Theil index in two additive components: the between-origin component $\left(\right.$ Theil $\left._{d, t, s}^{B, M i g}\right)$ and the within-origin component $\left(\right.$ Theil $\left._{d, t, s}^{W, M i g}\right)$. The former captures the extensive margin of the Theil Index, which implies a variation in the number of origin countries represented in the immigrants' population, while the latter capture the intensive margin, which is driven by the change of balance among immigrants groups. Analyzing the relation between the Theil index (and its components) and economic complexity can thus help exploring whether economic complexity correlates differently with a more diverse migrant population in terms of its composition (e.g., the distribution of the shares of each group) or, rather, the number of origin countries the migrants are coming from.

\subsection{The Economic Complexity Index}

Measuring a country's capabilities to produce and export, and quantifying how production and export performance impact future economic growth is challenging and has given rise to a vast literature (from early measures of productivity based on the Solow residual (Solow, 1956) to more advanced methodologies that incorporate socioeconomic indicators to measure countries' growth capacity. Our paper focuses on one such measure, namely the Economic Complexity Index (ECI) developed by Hidalgo and Hausmann (2009). The ECI aims to capture a country's accumulated capabilities or productive know-how. Countries with highly diversified export baskets which in turn include goods exported by fewer countries have higher levels of economic complexity. Hidalgo and Hausmann (2009) and Hausmann et al. (2014) document that higher levels of economic complexity positively relate to income per capita it that the ECI has a particularly strong explanatory power in predicting future economic growth (as compared to other long-established determinants of economic growth).

For our exercise we collect yearly ECI data for 222 countries from 1962 to 2016, from the Atlas of Economic Complexity by Hausmann et al. (2014) ! $^{6}$ As explained by Hausmann et al. (2014), the ECI is constructed using exports data for each country and year on nearly 800 tradable industries categorized using the SITC 4-digits classification.

As explained in Hidalgo and Hausmann (2009), the ECI is computed using product level export value data as main input. It organizes the export data for every year in the form of a matrix $M_{d p}$, sized $d \times p$, where a cell is 1 if country $d$ exports product $p$ with comparative advantage, and 0 otherwise. To quantify whether

\footnotetext{
${ }^{5}$ Namely, we compute $\mu_{d, t, s}$ as follow: $\mu_{d, t, s}=\frac{1}{N} \sum_{o}^{O} M I G_{d, o, t, s}$.

${ }^{6}$ Data are available from atlas.cid.harvard.edu
} 
a country exports a product with comparative advantage, the authors rely on the Revealed Comparative Advantage (RCA), originally suggested by Balassa (1965). The RCA for country $d$ and product $p$ for any year is computed according to the following formula:

$$
R C A_{d, p} \equiv \frac{\exp _{d, p} \sum_{p} \exp _{d, p}}{\sum_{d} \exp _{d, p} \sum_{d} \sum_{p} \exp _{d, p}}
$$

where $\exp _{d, p}$ is the exported value of product $p$ by country $d$. Thus, to create the $M_{d p}$ matrix, it is assumed that country $d$ exports product $p$ with comparative advantage if its RCA is 1 or more. This threshold can be interpreted as that country exporting that product in higher relative proportion than the World as a whole.

As a first step to compute ECI, $M_{d p}$ is used to quantify two indicators. First, for each country, the diversification of a country's export basket, measured as the number of products in which the country holds a RCA equal or greater than 1. Second, for each product, the number of countries that export such product with a RCA of one or more. The indexes of country diversification $\left(K_{d, 0}\right)$ and product ubiquity $\left(K_{p, 0}\right)$ are defined as follows:

$$
\begin{aligned}
& K_{d, 0}=\sum_{p} M_{d p} \\
& K_{p, 0}=\sum_{d} M_{d p}
\end{aligned}
$$

Equations (4) and (5) are the building blocks of the measure of economic complexity: countries with a more diverse export basket of less ubiquitous products are characterized by a high degree of economic complexity. The intuition is that both aspects (diversification and less ubiquitous products) require more know-how and capabilities (thus, countries export more varieties) that, in turn, are more exclusive and rare (thus, the varieties a country exports, on average, are less common).

The calculation of the ECI as explained by Hidalgo and Hausmann (2009) relies on the application of what they define as the Method of Reflections. The construction of the ECI is an iterative process. The method starts with $K_{d, 0}$ in its first iteration, as a measure of a country's complexity simply by counting the number of products it exports (in a given year). Then, it incorporates information on each one of those products using $K_{p, 0}$, and looks at the number of products $d$ exports weighted by the ubiquity of each one of them. It then incorporates the average diversification of the countries that export the same products as $d$, and iterates again and again, until converging. As explained by Hidalgo and Hausmann (2009), the $n$th iteration of this measure is:

$$
K_{d, n}=\frac{1}{K_{d, 0}} \sum_{p} M_{d p} \times K_{p, n-1}
$$


Where,

$$
K_{p, n-1}=\frac{1}{K_{p, 0}} \sum_{d} M_{d p} \times K_{d, n-2}
$$

Substituting (7) in (6), we have:

$$
K_{d, n}=\frac{1}{K_{d, 0}} \sum_{p} M_{d p} \times \frac{1}{K_{p, 0}} \sum_{d^{\prime}} M_{d^{\prime} p} \times K_{d^{\prime}, n-2}
$$

As shown by Hausmann et al. (2014), this expression can be rewritten as:

$$
K_{d, n}=\sum_{d^{\prime}} \widetilde{M_{d d^{\prime}}} \times K_{d^{\prime}, n-2}
$$

Where,

$$
\widetilde{M_{d d^{\prime}}}=\sum_{p} \frac{M_{d, p} M_{d^{\prime}, p}}{K_{d, 0} K_{p, 0}}
$$

Hausmann et al. (2014) note that equation (9) is satisfied when $K_{d, n}=K_{d, n-2}$ (e.g., convergence is achieved). Using matricial algebra, this corresponds to the eigenvector of $M_{d d^{\prime}}$ associated with the second largest eigenvalue (which captures most of the variance). Following their notation, let's call this eigenvector $\vec{K}$. Thus, the vector of all ECI values (one per country) is computed by standardizing $\vec{K}$ :

$$
E C I=\frac{\vec{K}-<\vec{K}>}{\operatorname{stdev}(\vec{K})}
$$

Where $<.>$ and $\operatorname{stdev}($.$) represent average and standard deviation, respectively.$

This calculation provides one ECI value for each country $d$ in every year, using data on its export basket.

Figure 2 plots the distribution of ECI values per country for year 2000. We can clearly see that the geographic distribution of the intensity in economic complexity is close to the one of birthplace diversity. Moreover, developed high-income societies are characterized by a high level of economic complexity, compared to developing/low-income countries. 
Figure 2: Economic Complexity Index 2000

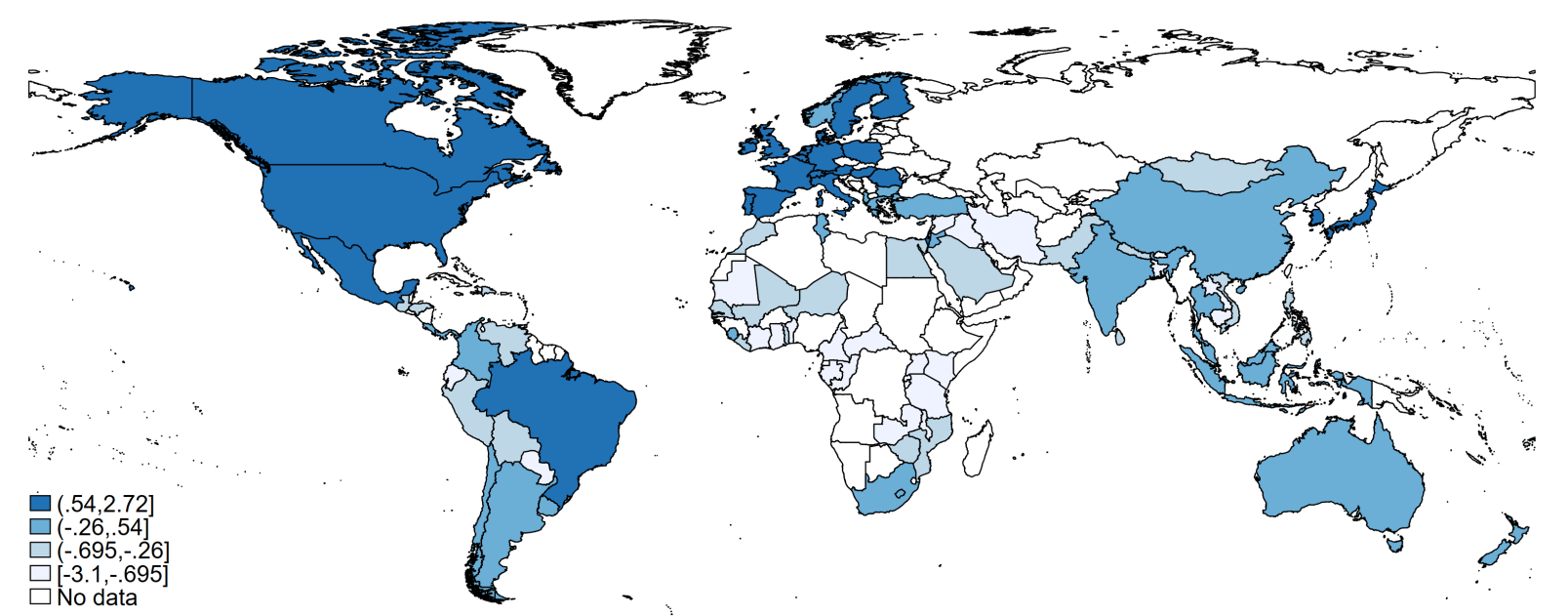

Note: authors' calculations using data from Hausmann et al. (2014). The map plot the standardized value of the Economic Complexity Index by country in year 2000 .

\subsection{Stylized facts}

While there is a literature that has focused on investigating the relationship between birthplace diversity and several economic outcomes such as income per capita or productivity, our focus is on economic complexity. We see three main reasons for such investigation. First, we suspect that economic complexity is prone to be influenced by the economic benefits in terms of skills and knowledge complementarities driven by immigration, in turn affecting other previously studied outcomes such as economic growth. Since countries' economic complexity increases with the accumulation of a country's stock of capabilities or know-how (as interpreted by Hidalgo and Hausmann (2009) and others), then we can conjecture that birthplace diversity should be positively related with economic complexity if new skills available in a more diverse society complement the available ones. Second, the nature of the ECI allows us to decompose it between export diversification and product uniqueness, allowing us to explore mechanisms through which diversity influences complexity. Third, even though the ECI has been shown to be an important determinant of income and growth, the evidence so far is thin when it comes to determining which factors influence the economic complexity of countries.

Figure 3 plots the evolution of the ECI and of immigrants' birthplace diversity over the period 1970-2000, respectively for the whole World and for developed/developing countries. Figure 3(a) shows an overall slight increase of the global average level of economic complexity, although there remain important differences between developed (OECD) and developing (non-OECD) economies. In terms of magnitude, the average level of ECI among developed economies is around ten time larger than the average level of developing economies, while the average yearly growth is larger for developing than for developed economies (1\% against $0.4 \%$ ). In turn, Figure 3 (b) plots average birthplace diversity per group of countries. Birthplace diversity follows a positive trend over time, similar to economic complexity, characterized by huge discrepancy between developed and developing economies. 
Figure 3: Evolution of Economic Complexity and Migrants Birthplace Diversity

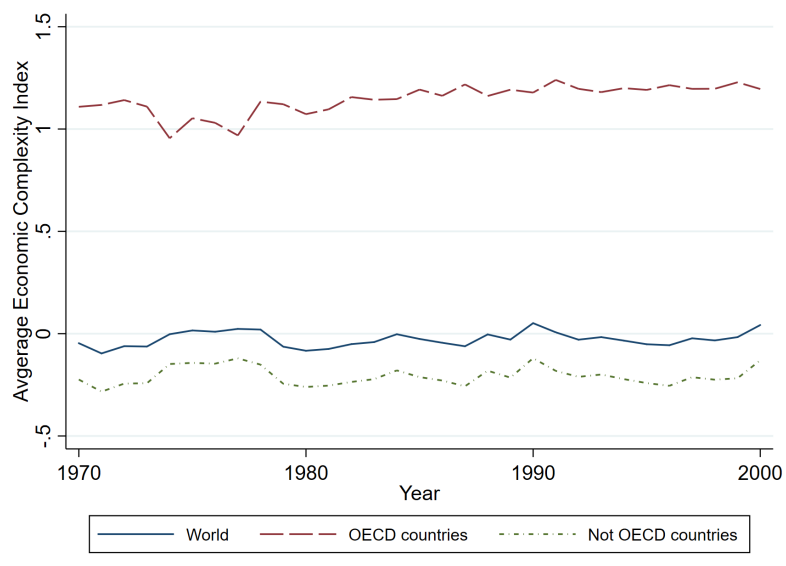

(a) Economic Complexity



(b) Immigrants Birthplace Diversity

Note: authors' calculations using data from Hausmann et al. (2014) and Özden et al. (2011). Figure (a) plots the country average level of the standardized Economic Complexity, while Figure (b) plots the country average level of the standardized Immigrants Birthplace Diversity. Both figures show the World level, OECD countries and Not OECD countries.

Figure 4(a) plots the country-year standardized level of ECI over the logarithm of GDP per capita, showing a positive and clear relation between the level of complexity and growth across countries, consistently with Hidalgo and Hausmann (2009) and Hausmann et al. (2014), among others. Figure 4(b) shows a similar although less prominent positive relation between economic complexity and migrants birthplace diversity. This relation remains similar and stable even when we differentiate between highly educated and less educated migrants (Figures $4(\mathrm{c})$ and 4 (d), respectively).

The descriptive evidence, therefore, points toward a clear positive relation between economic complexity and birthplace diversity. However, a question arises: What is the relation between economic complexity, birthplace diversity and economic growth? Knowing from the literature that birthplace diversity positively affects countries' income, as an additional motivational exercise, we replicate in Table 1 columns (1), (3) and (5) the main analysis of Alesina et al. (2016), with our sample of countries. Using their same specification and controls, we consistently estimate a strong and positive relation between diversity and GDP per capita across countries (the latter in log terms) 7 In columns (2), (4) and (6) we include as additional control the ECI of the country. Interestingly the associated coefficient is always positive and significant. Note that when ECI is controlled for there is a significant reduction of the partial correlation between diversity and GDP per capita, of around $20 \%$. This suggests that ECI is, in part, one of the channels through which birthplace diversity affects income.

In the next section we dig deeper into the relationship between birthplace diversity and economic com-

\footnotetext{
${ }^{7}$ The set of controls includes both time variant and time-invariant controls. The set of time-variant controls includes measures of quality of institutions from Polity IV, population size, human capital and trade openness. Time-invariant controls are measures of absolute latitude, average temperature, landlocked dummies, measures of ethnic, genetic and linguistic diversity and measures of local diseases prevalence.
} 
Figure 4: Economic Complexity and Migrants Birthplace Diversity

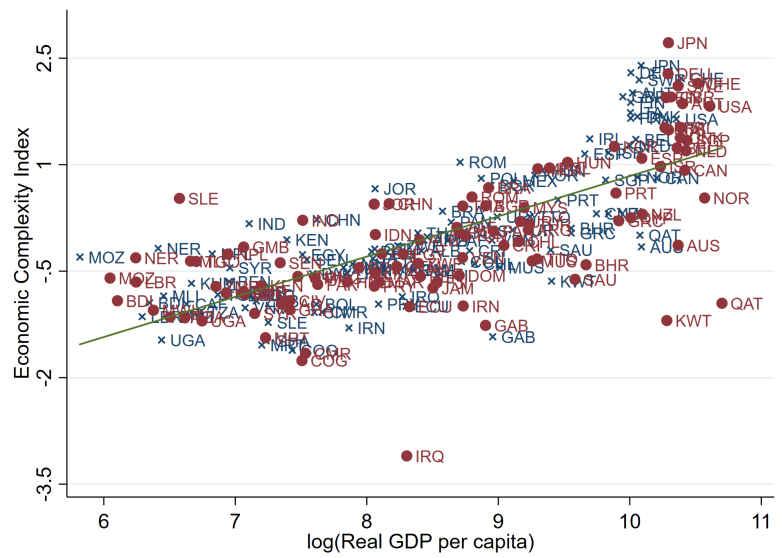

(a) GDP per Capita

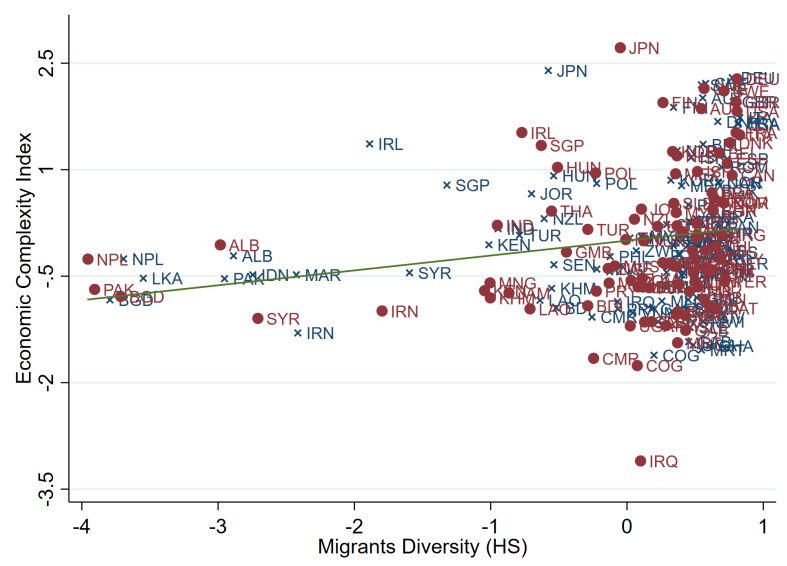

(c) HS Migrants



(b) All Migrants

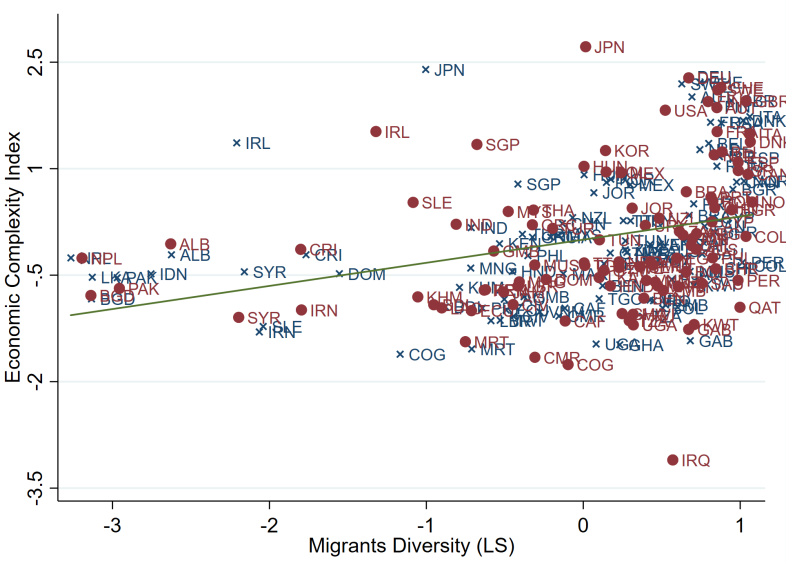

(d) LS Migrants

Note: authors' calculations using data from Hausmann et al. (2014) and ADOP (2015). Figures (a), (b), (c) and (d) plot the country level of the standardized Economic complexity index (y-axis) on the country level of the logarithm of real GDP per capita (fig (a)) and on the standardized migrants birthplace diversity index by skill group. All the correlations are statistically significant. Blue cross shows the country-observation in the 1990, while red dot shows the country-observation in the 2000.

plexity. 
Table 1: Replication of Alesina et al. (2016) controlling for Economic Complexity

\begin{tabular}{|c|c|c|c|c|c|c|}
\hline \multirow{2}{*}{$\begin{array}{l}\text { Dep. Variable: } \\
\ln (G D P)\end{array}$} & $\begin{array}{l}\text { (1) } \\
\text { OLS }\end{array}$ & $\begin{array}{c}(2) \\
\text { OLS }\end{array}$ & $\begin{array}{c}(3) \\
\text { OLS }\end{array}$ & $\begin{array}{c}(4) \\
\text { OLS }\end{array}$ & $\begin{array}{c}(5) \\
\text { OLS }\end{array}$ & $\begin{array}{c}\text { (6) } \\
\text { OLS }\end{array}$ \\
\hline & \multicolumn{2}{|c|}{ All Skill } & \multicolumn{2}{|c|}{ High Skill } & \multicolumn{2}{|c|}{ Low Skill } \\
\hline$D i v^{M i g}$ & $\begin{array}{c}0.177^{* * *} \\
(0.052)\end{array}$ & $\begin{array}{c}0.141^{* *} \\
(0.055)\end{array}$ & $\begin{array}{c}0.133^{* * *} \\
(0.051)\end{array}$ & $\begin{array}{l}0.100^{*} \\
(0.054)\end{array}$ & $\begin{array}{c}0.167^{* * *} \\
(0.051)\end{array}$ & $\begin{array}{c}0.135 * * \\
(0.053)\end{array}$ \\
\hline Mig & $\begin{array}{c}0.227^{* * *} \\
(0.067)\end{array}$ & $\begin{array}{c}0.214^{* * *} \\
(0.062)\end{array}$ & $\begin{array}{c}0.257^{* * *} \\
(0.064)\end{array}$ & $\begin{array}{c}0.232^{* * *} \\
(0.066)\end{array}$ & $\begin{array}{c}0.221^{* * *} \\
(0.068)\end{array}$ & $\begin{array}{c}0.206^{* * *} \\
(0.063)\end{array}$ \\
\hline$E C I$ & & $\begin{array}{l}0.196^{* *} \\
(0.081)\end{array}$ & & $\begin{array}{c}0.205^{* *} \\
(0.085)\end{array}$ & & $\begin{array}{l}0.197 * * \\
(0.081)\end{array}$ \\
\hline Observations & 200 & 200 & 200 & 200 & 200 & 200 \\
\hline Countries & 100 & 100 & 100 & 100 & 100 & 100 \\
\hline Adj. R-Square & 0.90 & 0.90 & 0.89 & 0.89 & 0.89 & 0.90 \\
\hline Controls & $\checkmark$ & $\checkmark$ & $\checkmark$ & $\checkmark$ & $\checkmark$ & $\checkmark$ \\
\hline Regional FE & $\checkmark$ & $\checkmark$ & $\checkmark$ & $\checkmark$ & $\checkmark$ & $\checkmark$ \\
\hline $\begin{array}{l}\text { Note: authors } \\
(2016) \text {. Standard } \\
\text { dependent variabl } \\
\text { set of controls of }\end{array}$ & $\begin{array}{l}\text { alculatic } \\
\text { ors are c } \\
\text { the log }\end{array}$ & $\begin{array}{l}\text { using dat } \\
\text { ered at c } \\
\text { im of rea } \\
\text { ina et al. }\end{array}$ & $\begin{array}{l}\text { rom Haus } \\
\text { htry level. } \\
\text { DP per ce } \\
016 \text {. }\end{array}$ & $\begin{array}{l}\mathrm{mn} \text { et al. } \\
<0.1, * * \\
\text { a. Each } \mathrm{r}\end{array}$ & $\begin{array}{l}2014) \text { and } \sqrt{\mathrm{A}} \\
0<0.05, * * * \mathrm{p} \\
\text { gression incl }\end{array}$ & $\begin{array}{l}\text { lesina et al. } \\
<0.01 \text {. The } \\
\text { udes the full }\end{array}$ \\
\hline
\end{tabular}

\section{Empirical Strategy}

We follow Alesina et al. (2016) as benchmark model for our analysis. We first replace their dependent variable with the $E C I_{d, t}$ as defined above. Our baseline specification is 8

$$
E C I_{d, t}=\alpha+\beta D i v_{d, t, s}^{M i g}+\gamma M i g_{d, t, s}+\delta \ln (G D P p c)_{d, t}+\Theta X_{d, t}+\Lambda Z_{d}+\eta_{t}+\epsilon_{d, t}
$$

Where $d$ indexes a country and $t$ a year. The main variable of interest is $D i v_{d, t, s}^{M i g}$, which represents a skill-specific birthplace diversity index among immigrants. In particular $s \in\{A l l, H S, L S\}$, which represent all migrants $(A l l)$, high-skilled $(H S)$, and low-skilled $(L S)$.

As controls we include a number of variables. First, $M i g_{d, t, s}$, which measures the skill-specific share of immigrants in destination country $d$ at year $t$ and skill group $s$. We also include as an additional control the logarithm of real GDP per capita in the country under consideration $(d)$, which aims to control for development levels. We know that, indeed, there is a strong correlation between ECI and income per capita and that by controlling for it, we are estimating whether birthplace diversity can explain higher economic complexity regardless of income per capita. The vector $X_{d, t}$ contains a set of country time-variant characteristics. This exhaustive list of controls aims to reduce concerns that our estimates are driven by omitted variable bias

\footnotetext{
${ }^{8} \mathrm{An}$ alternative specification we considered is to explore changes in $E C I$ as the dependent variable, instead of levels. However, this generates important challenges in terms of interpretation given that by construction ECI is standardized to have zero mean and unit standard deviation for every year. More generally, Broekel (2019) suggests there are issues involved when variables constructed using the method of reflections, such as ECI, are used in an inter-temporal setting. Nevertheless, Table A-I in the Online Appendix presents results using as dependent variable changes in ECI (after applying the inverse hyperbolic sine) and in $E C I$-based country rankings.
} 
from a number of observables. The controls include: (i) quality of institutions measured using the Polity-2 score from the Polity IV database (Marshall et al., 2013), (ii) population size from the UN database (United Nations, 2013) (iii) country-level aggregated years of schooling from Barro and Lee (2013), (iv) real trade openness from the PWT 8.0, (v) trade diversity of imports and exports (measured following Feenstra et al., 2005), and (vi) the weighted average of GDP per capita from all origin countries of immigrants to country $d$ using immigration shares as weights. The vector $Z_{d}$ contains a set of country time-invariant characteristics, such as: (i) landlocked dummies from Head et al., 2010, (ii) absolute latitude and share of population within $100 \mathrm{~km}$ of an ice-free coast (iii) average temperature and precipitation, (iv) continent fixed effects, (v) measures of ethnic, linguistic and genetic diversity of the local population from Alesina et al. 2003 and Ashraf and Galor 2013, and (vi) measures of prevalence of diseases such as malaria, tuberculosis or yellow fever, from World Bank, 2013. $\eta_{t}$ represents year fixed-effects.

Estimating equation 12 using OLS allows us to obtain an estimate of the partial correlation between economic complexity and immigration diversity, captured by $\beta$. However, in spite of the inclusion of a large number of time-variant and invariant controls, it is likely that unobserved factors captured by $\epsilon_{d, t}$ may be correlated with both immigrants' diversity and economic complexity. In that case our estimated OLS coefficient would be a biased estimate of the causal effect of diversity on economic complexity. To mitigate potential endogeneity concerns, we do two things: we first reduce the potential unobserved factors driven by immigration by accounting for potential confounders such as "epidemiological" factors and past-diversity and by including country fixed effects; and second we rely on an instrumental variable strategy.

\subsection{Accounting for unobserved heterogeneity}

To clarify whether the effects of immigration diversity are driven by a diverse set of skills and competences and not by the fact that immigrants are coming from more economically complex societies, we follow the literature on epidemiological effects (e.g., Spilimbergo, 2009; Docquier et al., 2016; Valette, 2018) by including as additional control an origin-specific effect $\overline{E C I}_{d, t, s}^{w}$, which is the weighted average of the $E C I$ in the origin countries of the immigrants to destination country $d$. Using as weights the shares of immigrants by skill and origin, $\overline{E C I}_{d, t, s}^{w}$ is a measure for destination country $d$ at year $t$ of its exposure to economic complexity driven by international migration. We compute this measure as follows:

$$
\overline{E C I}_{d, t, s}^{w}=\sum_{o}\left(\frac{M I G_{d, o, t, s}}{\sum_{o} M I G_{d, o, t, s}} \overline{E C I}_{o}^{1990-2000}\right)
$$

where $\overline{E C I}_{o}^{1990-2000}$ is the average ECI at origin country o over the period 1990-2000. If the effect of immigration is mainly driven by the level of economic complexity brought by immigrants, the estimated coefficient related to birthplace diversity should become statistically not significant once that term is controlled for.

Another potential omitted factor related to immigration and diversity is that immigration can have a persistent/long run effect. If that is the case, the partial correlation $\beta$ estimated in equation 12 can include 
also the effects of previously arrived immigrants. To precisely estimate the effect on economic complexity of recently arrived immigrants, we use Özden et al. (2011)'s data and compute a measure of immigrants birthplace diversity and share in 1960. Since data on the skill composition of immigrants are not available before 1990, we compute it (for the year 1960) over the whole immigrant population regardless of skill levels. Those controls will capture whether the effect of immigration are driven by previous cohorts of immigrants or by second/third generation immigration diversity.

Although we minimize the potential bias driven by omitted factors related to immigration, there could still be omitted factors related to destination countries that will bias our estimates. To deal with this issue, we perform two different analyses. First, we include in our cross-country sample country fixed-effects, accounting for time-invariant country specific unobserved heterogeneity. Being aware of the short time dimension of our data set $(T=2)$, the time-invariant factor can capture the majority of the variation associated to the dependent variable, providing imprecise estimates of the coefficients associated to our main variable of interest. Second, to overcome this issue driven by the reduced time dimension, we merge and harmonize the Database on Immigrants in OECD Countries (DIOC) and the ADOP (2015) data to have a short panel of 22 destination countries covering three time periods $(1990,2000$ and 2010) 9 Due to data limitations and to the fact that DIOC focuses on developed economies, we cannot cover the same sample as in our main cross-country analysis. However, having such a panel of countries is quite unique, since for each of them we have the bilateral education specific migration stocks from 194 origin countries ${ }^{10}$ allowing us to build our educationspecific birthplace diversity indexes for the relevant immigrant populations. Over this smaller panel we then estimate the following equation:

$$
E C I_{d, t}=\alpha+\beta_{p} D i v_{d, t, s}^{M i g}+\gamma_{p} M i g_{d, t, s}+\delta_{p} \ln (G D P p c)_{d, t}+\zeta_{p} H C_{d, t}+\eta_{d}+\eta_{t}+\epsilon_{d, t} .
$$

The estimated coefficient $\beta_{p}$ captures the partial correlation of diversity among immigrants on economic complexity after controlling for all time-invariant characteristics of destination countries through the inclusion of country fixed-effects $\eta_{d}$. Moreover we also include in the specification a standardized index of human capital, $H C_{d, t}$, based on the average years of schooling attained from Barro and Lee (2013) and taken from the Penn World Table (Feenstra et al., 2015). Including such index allows us to compare the effects of diversity and of human capital on economic complexity ${ }^{11}$ Equation 14 is empirically demanding, given the small number of countries and the short time dimension of the panel $(\mathrm{T}=3)$. However finding significant estimates even in such a short panel analysis should minimize concerns related to omitted variable bias.

\footnotetext{
${ }^{9}$ The harmonization of those data sets is explained in Appendix A

${ }^{10}$ The only exception is Germany, since from DIOC we have information only for 51 origin countries.

11 Docquier et al. (2019) show that human capital has a bigger role than birthplace diversity in explaining the economic growth of US States over the period 1990-2010.
} 


\subsection{Identification Strategy}

Since immigration is not a random process, another possible threat to our empirical strategy is the presence of a potential reverse causation bias. Countries that are more economically complex are also, on average, richer. Due to better economic conditions, those countries could attract a larger inflow of immigrants coming from a wider range of origin countries. If that is the case, the estimated coefficient $\beta$ in equation 12 will not give us any relevant information about the causal relation between diversity and economic complexity. To deal with reverse causation, we follow the literature and use two different two-stage least square estimators to predict skill-origin specific bilateral stocks of migrants. Our first IV strategy is based on Alesina et al. (2016), who proposed a gravity model to predict the bilateral stocks of immigrants. To minimize the possible violation of the exclusion restriction, the gravity model proposed is quite parsimonious. The model of bilateral migration is defined as:

$$
\begin{aligned}
M_{I G_{d, o, t, s}=} & \alpha+\gamma_{1} \text { Pop }_{d, 1960}+\gamma_{2} \text { Dist }_{d, o}+\gamma_{3} \text { Border }_{d, o}+\gamma_{4} \text { Lang Off }_{d, o} \\
& +\gamma_{5} \text { Lang eth }_{d, o}+\gamma_{6} \text { Colony }_{d, o}+\gamma_{7} \text { Time Zone }_{d, o}+\zeta_{o, t}+\eta_{t}+\epsilon_{d, o, t, s}
\end{aligned}
$$

where $M I G_{d, o, t, s}$ is the stock of immigrants from country of origin $o$ in destination country $d$ with education $s$ at year $t$. The set of controls includes the population in destination country $d$ in 1960 , the bilateral weighted distance, the presence of a common border, dummies for common official and ethnic minority languages, previous colonial ties and time zone differences ${ }^{12}$ We also include year fixed-effects to capture common trends across countries $\left(\eta_{t}\right)$ and origin-year specific fixed effects, to capture origin country specific trends $\left(\zeta_{o, t}\right)$. Due to the high number of zeros given by empty bilateral corridors, we estimate equation (15) using a Pseudo-Poisson Maximum Likelihood estimator (PPML) (see Santos Silva and Tenreyro (2006)). We then use the predicted coefficients associated to the estimated gravity equation 15 to predict the skillspecific bilateral stocks of migrants $\left(\widetilde{M I G}_{d, o, t, s}\right)$ and, with them, we compute the predicted skill-specific birthplace diversity indexes $\left(\widetilde{D i v}_{d, t, s}^{\text {Grav }}\right)$ and immigration shares $\left(\widetilde{M i g}_{d, t, s}^{\text {Grav }}\right)$. Since the estimated bilateral stocks are less driven by destination countries economic factors, we then use the resulting predicted diversity and share of immigration as IVs.

The second IV approach is based on a shift-share methodology (e.g., Card, 2001; Ottaviano and Peri, 2006; Docquier et al. 2019). The intuition for this approach is to use past immigration settlement patterns as predictor of subsequent migration flows due to network effects. Those predicted flows should be uncorrelated (or at least less correlated) with current levels of economic complexity and development. The variation in aggregate flows of immigrants across origin countries, which is mainly driven by origin-specific push factors, are allocated to our sample of destination countries according to the early distribution of immigrants from the same country of origin. Hence such shift-share instruments produce variation in immigration across

\footnotetext{
${ }^{12}$ Data and methodology from Head et al. (2010) and CEPII. The weighted distance is based on distances between the biggest cities in the countries weighted by the share of the city in the overall country population.
} 
destination countries over time due to the interaction between previously established immigrants' settlements and current emigration flows. Following Moriconi et al. (2018), we construct skill-specific bilateral stocks taking into account the aggregate variation of immigrant flows by skill and origin, and apply it to the same distribution of immigrants by origin. Using Özden et al. (2011) we compute the initial presence of immigrants from origin country $o$ in destination country $d$ in 1970 as share of the total immigration from the same origin country as follow:

$$
s h_{d, o, 1970}^{m i g}=\frac{M I G_{d, o, 1970}}{\sum_{d}^{D} M I G_{d, o, 1970}}
$$

where $M I G_{d, o, 1970}$ is the stock of migrants from origin country $o$ in destination country $d$ in 1970 . Then we compute from the ADOP $(2015)$ data for $t \in\{1990,2000\}$ the total amount of immigrants coming from country $o$ with education $s$ living in our sample of countries as follows:

$$
\operatorname{TOT} M I G_{o, t, s}=\sum_{d}^{D} M I G_{d, o, t, s} .
$$

Finally we can compute the predicted bilateral stocks of immigrants in destination country $d$ with education $s$ in year $t$ as follows:

$$
\widetilde{M I G}_{d, t, s}^{S S}=\operatorname{TOT} M I G_{o, t, s} * s h_{d, o, 1970}^{m i g}
$$

We will use the imputed bilateral stocks from equation 18 to compute predicted skill-specific measures of

diversity $\left(\widetilde{D_{i v}} S S\right.$,t,s $)$ and migration shares $\left(\widetilde{M i} g_{d, t, s}^{S S}\right)$, which will be our instrumental variables. Since the initial distribution of immigrants is not skill-specific, this avoids the potential threat of destination countries specific capabilities to attract low/high educated immigrants. However, as pointed out for example by GoldsmithPinkham et al. (2020) or by Jaeger et al. (2018)), persistent local conditions that could influence initial immigrants location and economic complexity of destination countries could threaten our identification. To reduce this possible threat, we also perform our shift-share approach using the initial distribution of immigrants in an earlier period (namely, 1960).

\section{Main Results}

Table 2 presents our baseline results for equation (12). From column (1) to (4) we use as specification the same model as Alesina et al. (2016), while from column (5) to (8) we include also the logarithm of real GDP per capita. Columns (1) and (5) estimates are related to the overall diversity driven by immigrants, while in the other columns we report education-specific estimates. In column (1) we can appreciate a strong and positive correlation between birthplace diversity and economic complexity. Since the variable of interest and the dependent variable are standardized with mean zero and standard deviation equal to one, we can assess the magnitude of the effects. Given all other factors equal, a one standard deviation increase in the birthplace diversity index is associated with an increase in the economic complexity index of the destination country by 
0.18 standard deviation.

Table 2: OLS regression on Economic Complexity Index

\begin{tabular}{|c|c|c|c|c|c|c|c|c|}
\hline $\begin{array}{l}\text { Dep. Variable: } \\
E C I\end{array}$ & $\begin{array}{l}(1) \\
\text { OLS }\end{array}$ & $\begin{array}{c}(2) \\
\text { OLS }\end{array}$ & $\begin{array}{l}(3) \\
\text { OLS }\end{array}$ & $\begin{array}{l}(4) \\
\text { OLS }\end{array}$ & $\begin{array}{l}(5) \\
\text { OLS }\end{array}$ & $\begin{array}{c}(6) \\
\text { OLS }\end{array}$ & $\begin{array}{c}(7) \\
\text { OLS }\end{array}$ & $\begin{array}{c}(8) \\
\text { OLS }\end{array}$ \\
\hline$D i v_{A l l}^{M i g}$ & $\begin{array}{c}0.179^{* * *} \\
(0.054)\end{array}$ & & & & $\begin{array}{l}0.125^{*} \\
(0.064)\end{array}$ & & & \\
\hline Mig $_{A l l}$ & $\begin{array}{l}0.068 \\
(0.075)\end{array}$ & & & & $\begin{array}{l}-0.002 \\
(0.071)\end{array}$ & & & \\
\hline $\operatorname{Div}_{H S}^{M i g}$ & & $\begin{array}{c}0.160^{* * *} \\
(0.056)\end{array}$ & & $\begin{array}{c}0.077 \\
(0.089)\end{array}$ & & $\begin{array}{c}0.120^{* *} \\
(0.059)\end{array}$ & & $\begin{array}{c}0.087 \\
(0.076)\end{array}$ \\
\hline$M_{i g_{H S}}$ & & $\begin{array}{c}0.119 \\
(0.083)\end{array}$ & & $\begin{array}{c}0.113 \\
(0.111)\end{array}$ & & $\begin{array}{c}0.042 \\
(0.089)\end{array}$ & & $\begin{array}{l}0.081 \\
(0.112)\end{array}$ \\
\hline $\operatorname{Div}_{L S}^{M i g}$ & & & $\begin{array}{c}0.166^{* * *} \\
(0.053)\end{array}$ & $\begin{array}{c}0.101 \\
(0.082)\end{array}$ & & & $\begin{array}{l}0.115^{*} \\
(0.062)\end{array}$ & $\begin{array}{c}0.045 \\
(0.084)\end{array}$ \\
\hline$M i g_{L S}$ & & & $\begin{array}{c}0.074 \\
(0.076)\end{array}$ & $\begin{array}{l}-0.001 \\
(0.090)\end{array}$ & & & $\begin{array}{c}0.006 \\
(0.071)\end{array}$ & $\begin{array}{l}-0.049 \\
(0.086)\end{array}$ \\
\hline $\ln (G D P p c)$ & & & & & $\begin{array}{c}0.306^{* *} \\
(0.128)\end{array}$ & $\begin{array}{c}0.300^{* *} \\
(0.119)\end{array}$ & $\begin{array}{c}0.306^{* *} \\
(0.127)\end{array}$ & $\begin{array}{l}0.301^{* *} \\
(0.126)\end{array}$ \\
\hline HH Index Trade & $\begin{array}{c}0.010 \\
(0.355)\end{array}$ & $\begin{array}{c}0.135 \\
(0.384)\end{array}$ & $\begin{array}{l}-0.009 \\
(0.354)\end{array}$ & $\begin{array}{c}0.069 \\
(0.372)\end{array}$ & $\begin{array}{c}0.151 \\
(0.330)\end{array}$ & $\begin{array}{c}0.216 \\
(0.361)\end{array}$ & $\begin{array}{c}0.141 \\
(0.331)\end{array}$ & $\begin{array}{c}0.204 \\
(0.359)\end{array}$ \\
\hline Observa & 200 & 200 & 200 & 200 & 200 & 200 & 200 & 200 \\
\hline Countries & 100 & 100 & 100 & 100 & 100 & 100 & 100 & 100 \\
\hline Adj. R-Square & 0.74 & 0.74 & 0.73 & 0.73 & 0.75 & 0.75 & 0.75 & 0.75 \\
\hline $\begin{array}{l}\text { Controls } \\
\text { Regional FE }\end{array}$ & $\begin{array}{l}\checkmark \\
\checkmark\end{array}$ & $\begin{array}{l}\checkmark \\
\checkmark\end{array}$ & $\begin{array}{l}\checkmark \\
\checkmark\end{array}$ & $\begin{array}{l}\checkmark \\
\checkmark\end{array}$ & $\begin{array}{l}\checkmark \\
\checkmark\end{array}$ & $\begin{array}{l}\checkmark \\
\checkmark\end{array}$ & $\begin{array}{l}\checkmark \\
\checkmark\end{array}$ & $\begin{array}{l}\checkmark \\
\checkmark\end{array}$ \\
\hline
\end{tabular}

Note: authors' calculations using data from Hausmann et al. (2014) and Alesina et al. (2016). Standard errors are clustered at country level. ${ }^{*} \mathrm{p}<0.1,{ }^{* *} \mathrm{p}<0.05,{ }^{* * *} \mathrm{p}<0.01$. The dependent variable is a standardized measure of the Economic Complexity Index. Each regression includes the full set of controls of Table 3 of Alesina et al. (2016).

A reasonable prior is that if the main contribution of immigration diversity to countries' economic complexity is through skill complementarities, then estimates that rely on birthplace diversity among high-skilled migrants should result in a higher point estimate. As Alesina et al. (2016) and Docquier et al. (2019) point out, diversity among college educated immigrants has a positive and significant effect respectively on countries and on US states' economic performance while diversity among low-educated immigrants has a smaller and less robust effect. In that sense, investigating the skill-specific relation between diversity and economic complexity provides a more stringent test of this prior. We present the skill-specific results from columns (2) to (4), and from columns (6) to (8). The relation between economic complexity and skill-specific diversity appears robust across immigrants education groups, and there is no statistical difference between the point estimates of low and highly educated diversity indexes. Including both high and low educated birthplace diversity indexes (col. (4)) produces no significant results due to the high correlation between the two measures. However this will no longer be the case (i.e., the two coefficients become statistically different and 
actually low-skill diversity becomes insignificant) when we conduct a heterogeneity analysis and control for more characteristics in the next set of regressions.

The coefficient for the relative size of the immigrant population (the share of foreign-born) is also positive but not precisely estimated. The inclusion of GDP per capita as an additional control (col. (5) to (8)) results in a reduction of about $25 \%$ in the size $\beta$. However the estimated coefficients remain positive and statistically significant, in particular for diversity among highly educated immigrants ${ }^{13}$ Those results suggest a strong a positive correlation between diversity and economic complexity, regardless of income levels ${ }^{14}$

Since our sample includes both developed and developing economies, we can test for non-linearities in the relation between birthplace diversity and economic complexity. Our prior here is that in an economy with a low level of complexity, where the structure of the economy is such that most workers perform manual tasks and work in very small teams or even individually, there may be not much complementarity to expect to start with. Immigrants may well bring new sets of skills and knowledge but these cannot be combined in production due to the structure of the economy. In addition, other complementary inputs such as physical capital, infrastructures or best managerial practices may be missing as well, preventing poor countries from taking advantage of the opportunities linked to diversity.

In an attempt to capture potential heterogeneous effects, we therefore split our sample of countries by terciles of ECI and perform a subsample analysis for each tercile of the distribution. Table 3 presents the results by tercile. Columns (1) to (4) present the estimates for the first tercile, columns (5) to (8) for the second tercile and finally columns (9) to (12) for the upper tercile of the distribution. As in Table 2 . we present the estimates both for overall immigration diversity and for education-specific immigrants birthplace diversity. There are two main results we can take from Table 3 . First, immigrants birthplace diversity, in particular among highly educated immigrants, is positively and strongly associated with economic complexity of countries at intermediate levels of economic complexity (namely, in the $2^{\text {nd }}$ tercile of the distribution). Birthplace diversity among highly educated immigrants is strongly significant also in the more demanding specification where we control for both skill-specific measure of diversity (col. (8)). The correlation between diversity and economic complexity is not significant in the other terciles of the distribution. Those results suggest that diversity contributes to the accumulation of knowledge and abilities required to build up the economic complexity of developing countries but is less important for the most and least "complex" countries. Second, real GDP per capita is highly correlated with economic complexity only in the upper tercile of the distribution. Intuitively, this result suggests that birthplace diversity is a factor explaining economic complexity but only when the local population has the right enough skills and competences to be complemented by those brought by the immigrants.

We further test whether the positive and significant relationship between diversity among immigrants

\footnotetext{
${ }^{13}$ Note that the inclusion of GDP per capita could be a "bad control" for our analysis if it is determined simultaneously with our index of diversity (see Angrist and Pischke, 2009). Yet, we include it to reduce possible bias due to the established relation between countries' average level of development and their economic complexity.

${ }^{14}$ Since our benchmark analysis includes measures of import and export diversification, our estimates are capturing more than a relation between birthplace diversity and diversification of export and import baskets. Similarly, our estimates are robust to including as an additional control a measure of net inflow of foreign investment. These results are available upon request.
} 
Table 3: OLS regression on Economic Complexity Index - ECI Terciles

\begin{tabular}{|c|c|c|c|c|c|c|c|c|c|c|c|c|}
\hline $\begin{array}{l}\text { Dep. Variable: } \\
E C I\end{array}$ & $\begin{array}{l}(1) \\
\text { OLS }\end{array}$ & $\begin{array}{c}(2) \\
\text { OLS } \\
\text { First }\end{array}$ & $\begin{array}{c}\text { (3) } \\
\text { OLS } \\
\text { Tercile }\end{array}$ & $\begin{array}{l}\text { (4) } \\
\text { OLS }\end{array}$ & $\begin{array}{l}(5) \\
\text { OLS }\end{array}$ & $\begin{array}{c}\text { (6) } \\
\text { OLS } \\
\text { Second }\end{array}$ & $\begin{array}{l}\text { (7) } \\
\text { OLS }\end{array}$ & $\begin{array}{l}(8) \\
\text { OLS }\end{array}$ & $\begin{array}{l}(9) \\
\text { OLS }\end{array}$ & $\begin{array}{l}\text { (10) } \\
\text { OLS } \\
\text { Third }\end{array}$ & $\begin{array}{r}\text { (11) } \\
\text { OLS } \\
\text { Tercile }\end{array}$ & $\begin{array}{l}(12) \\
\text { OLS }\end{array}$ \\
\hline$D i v_{A l l}^{M i g}$ & $\begin{array}{l}-0.069 \\
(0.140)\end{array}$ & & & & $\begin{array}{c}0.165^{* *} \\
(0.071)\end{array}$ & & & & $\begin{array}{l}-0.201 \\
(0.147)\end{array}$ & & & \\
\hline Mig $_{A l l}$ & $\begin{array}{c}0.075 \\
(0.055)\end{array}$ & & & & $\begin{array}{c}0.065 \\
(0.064)\end{array}$ & & & & $\begin{array}{c}0.344 \\
(0.405)\end{array}$ & & & \\
\hline$D i v_{H S}^{M i g}$ & & $\begin{array}{l}-0.183 \\
(0.163)\end{array}$ & & $\begin{array}{l}-0.286 \\
(0.194)\end{array}$ & & $\begin{array}{c}0.141^{* * *} \\
(0.047)\end{array}$ & & $\begin{array}{c}0.128^{* *} \\
(0.058)\end{array}$ & & $\begin{array}{l}-0.046 \\
(0.131)\end{array}$ & & $\begin{array}{c}0.314 \\
(0.266)\end{array}$ \\
\hline $\mathrm{Mig}_{H S}$ & & $\begin{array}{c}0.163 \\
(0.109)\end{array}$ & & $\begin{array}{c}0.091 \\
(0.117)\end{array}$ & & $\begin{array}{l}-0.009 \\
(0.063)\end{array}$ & & $\begin{array}{l}-0.072 \\
(0.085)\end{array}$ & & $\begin{array}{c}0.037 \\
(0.210)\end{array}$ & & $\begin{array}{c}0.163 \\
(0.222)\end{array}$ \\
\hline$D i v_{L S}^{M i g}$ & & & $\begin{array}{l}-0.061 \\
(0.142)\end{array}$ & $\begin{array}{c}0.098 \\
(0.095)\end{array}$ & & & $\begin{array}{l}0.142^{*} \\
(0.078)\end{array}$ & $\begin{array}{c}0.024 \\
(0.087)\end{array}$ & & & $\begin{array}{l}-0.187 \\
(0.128)\end{array}$ & $\begin{array}{l}-0.462 \\
(0.287)\end{array}$ \\
\hline$M i g_{L S}$ & & & $\begin{array}{c}0.071 \\
(0.052)\end{array}$ & $\begin{array}{c}0.078 \\
(0.050)\end{array}$ & & & $\begin{array}{l}0.066 \\
(0.064)\end{array}$ & $\begin{array}{c}0.090 \\
(0.098)\end{array}$ & & & $\begin{array}{c}0.253 \\
(0.259)\end{array}$ & $\begin{array}{c}0.370 \\
(0.305)\end{array}$ \\
\hline $\ln (G D P p c)$ & $\begin{array}{c}0.012 \\
(0.110)\end{array}$ & $\begin{array}{c}0.013 \\
(0.113)\end{array}$ & $\begin{array}{c}0.015 \\
(0.111)\end{array}$ & $\begin{array}{l}-0.019 \\
(0.119)\end{array}$ & $\begin{array}{l}-0.030 \\
(0.115)\end{array}$ & $\begin{array}{c}0.063 \\
(0.074)\end{array}$ & $\begin{array}{l}-0.013 \\
(0.118)\end{array}$ & $\begin{array}{c}0.037 \\
(0.125)\end{array}$ & $\begin{array}{c}1.079^{* * *} \\
(0.214)\end{array}$ & $\begin{array}{c}1.083^{* * *} \\
(0.202)\end{array}$ & $\begin{array}{c}1.065^{* * *} \\
(0.219)\end{array}$ & $\begin{array}{c}0.877^{* * *} \\
(0.213)\end{array}$ \\
\hline Observations & 67 & 67 & 67 & 67 & 67 & 67 & 67 & 67 & 66 & 66 & 66 & 66 \\
\hline Countries & 42 & 42 & 42 & 42 & 44 & 44 & 44 & 44 & 36 & 36 & 36 & 36 \\
\hline Adj. R-Square & 0.18 & 0.25 & 0.18 & 0.24 & 0.31 & 0.37 & 0.28 & 0.34 & 0.80 & 0.78 & 0.80 & 0.80 \\
\hline Controls & $\checkmark$ & $\checkmark$ & $\checkmark$ & $\checkmark$ & $\checkmark$ & $\checkmark$ & $\checkmark$ & $\checkmark$ & $\checkmark$ & $\checkmark$ & $\checkmark$ & $\checkmark$ \\
\hline Regional FE & $\checkmark$ & $\checkmark$ & $\checkmark$ & $\checkmark$ & $\checkmark$ & $\checkmark$ & $\checkmark$ & $\checkmark$ & $\checkmark$ & $\checkmark$ & $\checkmark$ & $\checkmark$ \\
\hline
\end{tabular}

and economic complexity is robust to using alternative measures of diversity. Table B-2 in Appendix B shows the estimates over the sample of countries belonging to the $2^{\text {nd }}$ ECI tercile after including the number of immigrants' countries of origin represented (col. (2)), and after replacing the diversity indexes with polarization indexes (col. (3)) and Theil indexes and its decomposition (col. (4) to (6)). The estimates confirm the previous results: lower concentration (as measured by the Theil index, which is consistent with high diversity) is associated with higher economic complexity. Moreover, the significant coefficient associated to the between component of the Theil index (col. (6)) suggests that the positive relation between diversity and economic complexity is mainly driven by an expansion of the set of origin countries, which likely implies an introduction of new skills and competences in the destination country.

As explained in Section 3, the strong partial correlation found between diversity and complexity could be driven by unobserved factors. Immigrants coming from a wide range of origin countries can bring with them a wide set of skills and competences, but they can also bring with them knowledge driven by the economic complexity of their origin country. Following Valette (2018), we therefore include in our specification a measure of exposure to economic complexity driven by international migration $\left(\overline{E C I}_{s}^{w}\right)$. Table $\mathrm{B}-3$ in Appendix B presents the estimates for the full sample and for the subsample of countries in the $2^{\text {nd }}$ tercile of ECI. Once we include simultaneously the birthplace diversity index and the origin-specific term, the partial correlation between birthplace diversity and economic complexity remains positive and statistically 
significant. Those results suggest that the effect of immigration on economic complexity is driven by the variety of complementary skills and competences captured by birthplace diversity, and not by a simple transfer of complexity from origin to destination countries ${ }^{15}$

Another potential threat that could bias our estimates is the long-run/persistent effect of immigration. As pointed out by Alesina et al. (2016), our measure of birthplace diversity could also capture the effect of immigrants previously arrived in the destination country, and so our estimates would capture a combination of diversity driven by recent and older immigration. We thus include as additional control a measure of lagged diversity, to capture the effect of diversity driven by previous cohorts. We use Özden et al. (2011) data and construct as additional controls measures of immigrants diversity and shares in 1960. Table B-4 in Appendix B presents the estimates on the full sample and on the $2^{\text {nd }}$ tercile. The inclusion of past diversity as additional control affects the precision of the estimates related to current diversity in the full sample ${ }^{16}$ However, the estimates for current immigration diversity over the subsample of countries belonging to the $2^{\text {nd }}$ tercile are positive and significant, in particular among highly educated immigrants. This result confirms the relevant role of diversity in skills and competences driven by immigration in developing economies.

\section{Robustness}

After assessing a stable and positive correlation between immigrants diversity, particularly among highly educated immigrants, and economic complexity, this section investigates the robustness of those results.

We first test the robustness of our estimates to time-invariant unobserved heterogeneity by including in our sample country fixed-effects. The inclusion of time-invariant factors with a reduced time dimension $(\mathrm{T}=2)$ is extremely demanding from an empirical point of view, since the majority of the variation can be captured by country fixed-effects. Being aware of that, Table 4 presents the skill-specific estimates over the whole sample (col. (1) to (4)) and over the sample of countries belonging to the $2^{\text {nd }}$ tercile of the Economic Complexity index. Even though the estimates on the overall sample are not precisely estimated, columns (6) and (8) show that the positive relation between diversity among college educated immigrants and economic complexity is robust to the inclusion of time-invariant country-specific factors. However, given the small sample size and the short time dimension, those estimates should be interpreted cautiously.

Table 5 presents the results of our short panel for a sub-set of OECD countries only. Indeed, due to data limitations our short panel cover 22 destination countries ${ }^{17}$ over three periods $(1990,2000$ and

\footnotetext{
${ }^{15}$ The negative and significant estimates associated to the origin-specific term among countries belonging to the $2^{\text {nd }}$ ECI tercile suggests that the beneficial relation between migration and complexity is not necessarily driven by an increase of skills and competences coming from the most complex societies. However, such negative relation can be also explained by the fact that those countries are attracting more immigrants from less complex countries. Investigating the effect of diversity in a panel of the 51 US states, Docquier et al. 2019) find a similar negative relation between the origin-specific term and states economic growth.

${ }^{16}$ This result suggests that part of the strong correlation between current diversity and economic complexity is driven by previous cohorts of immigrants. Not surprisingly, current and past diversity are strongly correlated (at 0.70).

${ }^{17}$ The 22 destination countries in analysis are: Australia, Belgium, Canada, Denmark, Finland, France, Germany, Greece, Hungary, Ireland, Italy, Japan, Mexico, Netherlands, New Zealand, Norway, Poland, Portugal, Spain, Sweden, United Kingdom, United States.
} 
Table 4: OLS regression on Economic Complexity Index - Country fixed effects



Note: authors' calculations using data from Hausmann et al. (2014) and Alesina et al. (2016). Standard errors are clustered at country level. ${ }^{*} \mathrm{p}<0.1,{ }^{* *} \mathrm{p}<0.05,{ }^{* * *} \mathrm{p}<0.01$. The dependent variable is a standardized measure of the Economic Complexity Index. Each regression includes the full set of controls of Table 3 of Alesina et al. (2016) plus the logarithm of GDP. Moreover, each specification includes country fixed effects.

2010). However, thanks to the bilateral structure and the skill composition available in the harmonized data set we are able to compute skill specific measures of birthplace diversity for each destination country. Odd columns present the estimates of equation (14) without country specific control, while even columns include as additional control measures of human capital and GDP per capita. Moreover all the estimates include year and country fixed effects, controlling for common trends and for time-invariant country specific factors. The main results of this analysis are two. First, there is a strong and positive correlation between birthplace diversity and economic complexity also in a panel dimension. The results are stronger among highly educated immigrants. Including country-specific controls enhances the effect of diversity on economic complexity. Those results should minimize possible concerns related to an omitted variable bias. Second, human capital is another strong and good predictor of economic complexity. Since the measure of human capital is standardized as birthplace diversity 18 we can compare the magnitude of the two coefficients. Indeed, the effect of human capital on economic complexity is on average three times bigger than the effect

\footnotetext{
${ }^{18}$ Both measures are standardized with mean zero and standard deviation equal to one.
} 
Table 5: Panel Analysis on Economic Complexity Index

\begin{tabular}{|c|c|c|c|c|c|c|c|c|}
\hline $\begin{array}{l}\text { Dep. Variable: } \\
E C I\end{array}$ & $\begin{array}{l}(1) \\
\text { OLS }\end{array}$ & $\begin{array}{c}(2) \\
\text { OLS }\end{array}$ & $\begin{array}{c}(3) \\
\text { OLS }\end{array}$ & $\begin{array}{c}(4) \\
\text { OLS }\end{array}$ & $\begin{array}{c}(5) \\
\text { OLS }\end{array}$ & $\begin{array}{c}(6) \\
\text { OLS }\end{array}$ & $\begin{array}{c}(7) \\
\text { OLS }\end{array}$ & $\begin{array}{c}(8) \\
\text { OLS }\end{array}$ \\
\hline$D i v_{A l l}^{M i g}$ & $\begin{array}{c}0.120^{* *} \\
(0.045)\end{array}$ & $\begin{array}{c}0.159^{* * *} \\
(0.043)\end{array}$ & & & & & & \\
\hline Mig $_{A l l}$ & $\begin{array}{c}-0.353^{* *} \\
(0.162)\end{array}$ & $\begin{array}{c}-0.300^{* *} \\
(0.130)\end{array}$ & & & & & & \\
\hline$D i v_{H S}^{M i g}$ & & & $\begin{array}{c}0.085^{* *} \\
(0.041)\end{array}$ & $\begin{array}{c}0.151^{* *} \\
(0.066)\end{array}$ & & & $\begin{array}{c}0.197 \\
(0.145)\end{array}$ & $\begin{array}{l}0.286^{*} \\
(0.155)\end{array}$ \\
\hline $\mathrm{Mig}_{H S}$ & & & $\begin{array}{l}-0.132 \\
(0.081)\end{array}$ & $\begin{array}{l}-0.033 \\
(0.095)\end{array}$ & & & $\begin{array}{r}-0.157^{*} \\
(0.083)\end{array}$ & $\begin{array}{l}-0.057 \\
(0.092)\end{array}$ \\
\hline$D i v_{L S}^{M i g}$ & & & & & $\begin{array}{c}0.052 \\
(0.048)\end{array}$ & $\begin{array}{c}0.104^{* *} \\
(0.049)\end{array}$ & $\begin{array}{l}-0.076 \\
(0.117)\end{array}$ & $\begin{array}{l}-0.102 \\
(0.127)\end{array}$ \\
\hline $\operatorname{Mig}_{L S}$ & & & & & $\begin{array}{l}-0.097 \\
(0.082)\end{array}$ & $\begin{array}{l}-0.104 \\
(0.095)\end{array}$ & $\begin{array}{l}-0.153 \\
(0.095)\end{array}$ & $\begin{array}{l}-0.145 \\
(0.101)\end{array}$ \\
\hline$H C$ & & $\begin{array}{c}0.517^{* *} \\
(0.201)\end{array}$ & & $\begin{array}{c}0.559^{* *} \\
(0.246)\end{array}$ & & $\begin{array}{c}0.563^{* *} \\
(0.214)\end{array}$ & & $\begin{array}{c}0.554^{* *} \\
(0.236)\end{array}$ \\
\hline $\ln (G D P p c)$ & & $\begin{array}{l}-0.008 \\
(0.307)\end{array}$ & & $\begin{array}{l}-0.317 \\
(0.545)\end{array}$ & & $\begin{array}{l}-0.033 \\
(0.414)\end{array}$ & & $\begin{array}{l}-0.323 \\
(0.449)\end{array}$ \\
\hline Observations & 66 & 66 & 66 & 66 & 66 & 66 & 66 & 66 \\
\hline Countries & 22 & 22 & 22 & 22 & 22 & 22 & 22 & 22 \\
\hline Adj. R-Square & 0.95 & 0.96 & 0.95 & 0.96 & 0.95 & 0.96 & 0.95 & 0.96 \\
\hline Year FE & $\checkmark$ & $\checkmark$ & $\checkmark$ & $\checkmark$ & $\checkmark$ & $\checkmark$ & $\checkmark$ & $\checkmark$ \\
\hline Country FE & $\checkmark$ & $\checkmark$ & $\checkmark$ & & $\checkmark$ & $\checkmark$ & $\checkmark$ & $\checkmark$ \\
\hline $\begin{array}{l}\text { Note: authors } \\
\text { World Table. Stan } \\
\text { variable is a stand } \\
\text { year fixed effects. } \\
\text { logarithm of real } \\
\text { Canada, Denmark } \\
\text { New Zealand, Nor }\end{array}$ & $\begin{array}{l}\text { calculati } \\
\text { dard error } \\
\text { ardized me } \\
H C \text { is the } \\
\text { GDP per c } \\
\text { Finland, } \\
\text { way, Polal }\end{array}$ & $\begin{array}{l}\text { s using } d \mathrm{c} \\
\text { are cluster } \\
\text { sure of the } \\
\text { tandardize } \\
\text { oita. The } \\
\text { rance, Ger }\end{array}$ & $\begin{array}{l}\text { om } 1 \\
\text { coun } \\
\text { oomic } \\
\text { easur } \\
\text { f cou } \\
\text { Gre }\end{array}$ & $\begin{array}{l}\text { iann } \\
\text { vel. * } \\
\text { plexit } \\
\text { uman } \\
\text { in th } \\
\text { funga }\end{array}$ & $\begin{array}{l}2014 \\
\text { dex. E } \\
\text { ital }(\mathrm{P} \\
\text { nple is } \\
\text { eland. }\end{array}$ & $\begin{array}{l}\mathrm{DOP} \\
05, * * * \\
\text { regress } \\
\text { World } \\
\text { follow }\end{array}$ & $\begin{array}{l}\text { 155, DIC } \\
\text { a.01. T } \\
\text { includes } \\
\text { ble). In } \\
\text { : Austra } \\
\text { Mexico, }\end{array}$ & $\begin{array}{l}\text { and Penn } \\
\text { ependent } \\
\text { intry and } \\
P \text { ) is the } \\
\text { Belgium, } \\
\text { herlands, }\end{array}$ \\
\hline
\end{tabular}

of birthplace diversity. Those results are in line with Docquier et al. (2019), who find a ratio of four between those same two coefficients using US data at the US state level.

In Table 6 we test whether our results hold after instrumenting our main variable of interest. As discussed in Section 3, we have two different sets of instrumental variables. Descriptive statistics across different standardized instrumental variables and actual birthplace diversity and immigration share are available in Table C-I. Table C-II and Table C-III in the Online Appendix. Overall there is a strong correlation across different measures of diversity (actual and predicted). However, looking at correlations in Tables C-II and CIII] we can see that both IV approaches have some issues with the prediction of the stocks of highly educated immigrants. The gravity model is not able to predict properly the composition of the bilateral stocks of highly educated migrants in terms of countries of origin (i.e., diversity index), but it is able to produce a good predictor of the skill-specific share of immigrants. On the other hand, the shift-share approach is able to predict the composition in terms of countries of origin of college-educated immigrants, while it fails 
Table 6: IV regression on ECI



Note: authors' calculations using data from Hausmann et al. [2014], Alesina et al. [2016) Ö̈zden et al. [2011), and ADOP (2015). Standard errors are clustered at country level. $* \mathrm{p}<0.1,{ }^{* *} \mathrm{p}<0.05$, ${ }^{* * *} \mathrm{p}<0.01$. This table shows the effect of birthplace diversity on our standardized measure of Economic Complexity,after controlling for the full set of controls of Table 3 of Alesina et al. [2016) and for the logarithm of real GDP per capita. Birthplace diversity is instrumented with predicted stocks through shift-share methodology based on the 1970 distribution, while the migration share is instrumented with predicted stocks from gravity model.

to predict the size of immigrants population 19 To properly identify both endogenous variables we then instrument diversity indexes with IVs based on predicted stocks from the shift-share approach, while we instrument skill-specific shares of immigrants with IVs based on predicted stocks from the gravity model. Table 6 reports the second-stage estimates of our IV approach. Columns (1), (4) and (7) show the estimates

\footnotetext{
19 Docquier et al. $(2019)$ recognize the same weakness of the shift-share methodology to predict the share of college-graduate immigrants.
} 
when we instrument only the skill-specific diversity index, while columns (2), (5) and (8) present the estimates when the skill-specific share of immigrants is treated as endogenous variable. Finally, columns (3), (6) and (9) shows the estimates when both variables are simultaneously instrumented. Moreover our analysis is done over the whole sample of countries (Panel A) and the subsample of countries belonging to the $2^{\text {nd }}$ tercile of the economic complexity distribution (Panel B). Looking at both panels, the instrumental variables have enough predictive power to explain both endogenous variables when we instrument them separately and simultaneously. The F-stat are always above the critical values specified by Stock and Yogo (2002). The estimates associated to birthplace diversity indexes are always positive and significant on the overall sample (Panel A), confirming the results presented in Table 2. The estimates presented in Panel B are positive and precisely estimated at the $1 \%$ level. Moreover, all the 2SLS point estimates are larger than the OLS estimates presented in Table 3 when we instrument both endogenous variables, suggesting the correction of an attenuation bias.

Overall we can see that the coefficients associated to birthplace diversity are positive and significant across different regressions, confirming the strong and positive relationship between diversity and economic complexity in countries that belong to the middle of the economic complexity distribution 20

\section{Discussion}

Our analysis shows a clear and strong correlation between immigrants' birthplace diversity and economic complexity. Our estimates are stronger when focusing on college educated immigrants and among developing countries at intermediate levels of economic complexity. Those results are robust to the inclusion of historical diversity, origin-specific effects, country fixed-effects and panel analysis. Combining those robustness with our IV estimates, we mitigate the potential reverse causality and omitted variable bias threats, reducing concerns that our results are being driven by endogeneity.

However, some questions remain open. For instance, what are the mechanisms through which immigrants diversity positively affects economic complexity? Empirically determining these mechanisms is an important part of our future agenda, but here we provide some insights.

Simply put, a higher Economic Complexity Index is driven by two components. First, a more diverse export basket in terms of the number of manufactured goods that are exported competitively; and second, a smaller average number of countries that export those industries competitively (a low ubiquity of those industries). We extend our analysis by testing whether birthplace diversity of a country contributes to its export basket diversity and/or to the uniqueness of its products.

Following the literature, we compute different indices to measure the diversification of a country's export basket (see Imbs and Wacziarg, 2003, Cadot et al. 2011, Bahar and Santos, 2018) using - consistently with the construction of ECI above - 4-digit classification of industries according to SITC. We first construct an index

\footnotetext{
${ }^{20}$ Second-stage estimates with alternative shift-share stocks based on the 1960 distribution are available in Table B-II in the Online Appendix.
} 
that measures concentration of a country's export basket (e.g., a larger value implies higher concentration, or less diversification), namely the Herfindahl-Hirschman index (HHI here onwards) ${ }^{21}$ Assuming there are $i=1,2, \ldots, n$ products and $d=1,2, \ldots, m$ countries, the HHI for any country $d$ in time $t$ is computed using the following formula:

$$
H H I_{d, t}=\sum_{i=1}^{n} s_{i, d, t}^{2}
$$

where $s_{i, d, t}$ is the share of product $i$ in country $d$ 's export basket at time $t$. We complement it with two additional measures. First, the total number of 4-digit SITC industries exported with any value higher than zero; and second with the total number of products exported by a country $d$ at time $t$ with RCA values above one, consistently with the economic complexity literature. Naturally, for these two measures a higher value implies more export diversification (and less concentration). These measures can be mathematically expressed as:

$$
\begin{aligned}
\text { products }_{d, t} & =\sum_{i=1}^{n} \times 1\left[\exp _{i, d, t}>0\right] \\
\text { productsRC } A_{d, t} & =\sum_{i=1}^{n} \times 1\left[r c a_{i, d, t} \geq 1\right]
\end{aligned}
$$

We then also compute a number of indices to measure the average ubiquity of a country's exports. Firstly we compute the concentration of each product in the global export basket, applying the HHI index formula to a product $p$ as follows:

$$
H H I_{p, t}=\sum_{j=1}^{m} s_{p, j, t}^{2}
$$

where $j$ represents a country, and $s_{p, j, t}$ is the share of product $p$ in country $j$ 's export basket at time $t$. A higher value of $\mathrm{HHI}_{p, t}$ implies that exports of product $p$ in time $t$ are concentrated on fewer countries. We then compute a country level measure which we name $H H I^{p}$, constructed as:

$$
H H I_{d, t}^{p}=\sum_{i=1}^{n} s_{i, d, t} \times H H I_{i, t}
$$

In other words, $H H I_{d, t}^{p}$ is a sum of product-level concentration indices weighted by the relative size of each product in country $d$ 's export basket at time $t$. A higher value of $H H I_{d, t}^{p}$ implies that country $d$ exports goods that are exported by fewer countries at time $t$. Consistently with the above, we produce similar measures for

\footnotetext{
${ }^{21}$ We also compute alternative indices of product diversification: the Gini coefficient, the Theil Index with its decomposition in the Theil-within and Theil-between. Changes in the Theil-within can be interpreted as changes in concentration due to more concentration of industries that already existed in the export basket of the country, while the Theil-between can be interpreted as changes in export concentration due to the appearance or disappearance of export lines. Results related to those indices and others are reported in Tables D-I and D-III of the Online Appendix.
} 
the countries that export product $p$ based on the following two definitions:

$$
\begin{aligned}
\text { countries }_{p, t} & =\sum_{j=1}^{m} \times 1\left[\exp _{p, j, t}>0\right] \\
\text { countriesRC } A_{p, t} & =\sum_{j=1}^{m} \times 1\left[r c a_{p, j, t} \geq 1\right]
\end{aligned}
$$

Then we use these measures to construct a country-level variable that computes the average export shares weighted by number of countries that export each product exported by country $c$ as follow:

$$
\begin{aligned}
\operatorname{products}_{d, t}^{p} & =\sum_{i=1}^{n} s_{i, d, t} \times \text { countries }_{i, t} \\
\text { products } R C A_{d, t}^{p} & =\sum_{i=1}^{n} s_{i, d, t} \times \text { countries } R C A_{i, t}
\end{aligned}
$$

\begin{tabular}{|c|c|c|c|c|c|c|c|c|c|c|}
\hline & $\begin{array}{c}(1) \\
E C I\end{array}$ & $\begin{array}{c}(2) \\
\ln (G D P p c)\end{array}$ & $\begin{array}{c}(3) \\
D i v_{A l l}^{M i g}\end{array}$ & $\begin{array}{c}(4) \\
D i v_{H S}^{M i g}\end{array}$ & $\begin{array}{c}(5) \\
\operatorname{Div}{ }_{L S}^{M i g}\end{array}$ & $\begin{array}{c}(6) \\
H H I\end{array}$ & $\begin{array}{c}(7) \\
\text { products }\end{array}$ & $\begin{array}{c}(8) \\
\text { productsRCA }\end{array}$ & $\begin{array}{c}(9) \\
H H I^{p}\end{array}$ & $\begin{array}{c}(10) \\
\text { products }^{p}\end{array}$ \\
\hline$\overline{E E C I}$ & 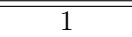 & & & & & & & & & \\
\hline $\ln (G D P p c)$ & $0.720^{* * *}$ & 1 & & & & & & & & \\
\hline$D i v_{A l l}^{M i g}$ & $0.338^{* * *}$ & $0.447^{* * *}$ & 1 & & & & & & & \\
\hline$D i v_{H S}^{M i g}$ & $0.209^{* *}$ & $0.295^{* * *}$ & $0.869^{* * *}$ & 1 & & & & & & \\
\hline$D i v_{L S}^{M i g}$ & $0.326^{* * *}$ & $0.427^{* * *}$ & $0.993 * * *$ & $0.841 * * *$ & 1 & & & & & \\
\hline$H H I$ & $-0.557 * * *$ & $-0.308^{* * *}$ & -0.109 & -0.0477 & -0.0872 & 1 & & & & \\
\hline products & $0.697^{* * *}$ & $0.716^{* * *}$ & $0.342^{* * *}$ & $0.144^{*}$ & $0.321^{* * *}$ & $-0.568 * * *$ & 1 & & & \\
\hline products $R C A$ & $0.811^{* * *}$ & $0.584^{* * *}$ & $0.305^{* * *}$ & $0.171^{*}$ & $0.291^{* * *}$ & $-0.613^{* * *}$ & $0.754^{* * *}$ & 1 & & \\
\hline$H H I^{p}$ & 0.137 & -0.0717 & 0.00592 & 0.0660 & 0.00936 & $-0.353^{* * *}$ & -0.0348 & $0.201^{* *}$ & 1 & \\
\hline products $^{p}$ & $0.306^{* * *}$ & $0.139^{*}$ & 0.00228 & -0.0268 & -0.0221 & $-0.339 * * *$ & $0.316^{* * *}$ & $0.369 * * *$ & $-0.213^{* *}$ & 1 \\
\hline products $R C A^{p}$ & $-0.499 * * *$ & $-0.364^{* * *}$ & $-0.188^{* *}$ & $-0.175^{*}$ & $-0.185^{* *}$ & 0.134 & $-0.290^{* * *}$ & $-0.458^{* * *}$ & $-0.402^{* * *}$ & $0.244^{* * *}$ \\
\hline
\end{tabular}

In other words, lower levels of $\operatorname{products}_{d, t}^{p}$ and of productsRC $A_{d, t}^{p}$ imply that country-year pair $d$ and $t$ is exporting products that, on average, are less ubiquitous.

Table 7: Correlations of diversity, diversification, ubiquity, income and complexity

Table 7 shows the correlation across those measures of diversification, export uniqueness and our measures of birthplace diversity, GDP per capita as well as ECI. The table documents that, naturally, all diversification measures are highly and significantly correlated among each other. But, in addition, the table also documents that economic complexity and immigration diversity are positively correlated with measures of export diversification (or, in fact, negatively correlated with measures of concentration). Concerning measures of export uniqueness we find a negative and significant correlation between our weighted measures of competitive products and diversity, suggesting that more diversity is related with less ubiquitously exported goods.

Table 8 estimates equation (12), but this time uses the export basket diversification and uniqueness 
Table 8: OLS regression on Diversification and Ubiquity Measures

\begin{tabular}{|c|c|c|c|c|c|c|c|c|c|}
\hline & \multicolumn{3}{|c|}{$H H I$} & \multicolumn{3}{|c|}{ products } & \multicolumn{3}{|c|}{ products $R C A$} \\
\hline & (1) & $(2)$ & (3) & (4) & $(5)$ & (6) & (7) & (8) & (9) \\
\hline \multicolumn{10}{|c|}{ Panel A - Diversification } \\
\hline$D i v_{A l l}^{M i g}$ & $\begin{array}{l}-0.007 \\
(0.019)\end{array}$ & & & $\begin{array}{c}7.975 \\
(11.653)\end{array}$ & & & $\begin{array}{c}11.438^{* *} \\
(4.558)\end{array}$ & & \\
\hline$M i g_{A l l}$ & $\begin{array}{l}-0.024 \\
(0.020)\end{array}$ & & & $\begin{array}{c}-5.090 \\
(14.611)\end{array}$ & & & $\begin{array}{c}1.525 \\
(4.615)\end{array}$ & & \\
\hline$D i v_{H S}^{M i g}$ & & $\begin{array}{l}-0.006 \\
(0.018)\end{array}$ & & & $\begin{array}{l}-11.402 \\
(12.545)\end{array}$ & & & $\begin{array}{c}12.687^{* * *} \\
(4.567)\end{array}$ & \\
\hline$M i g_{H S}$ & & $\begin{array}{l}-0.033 \\
(0.031)\end{array}$ & & & $\begin{array}{c}-7.664 \\
(15.428)\end{array}$ & & & $\begin{array}{l}-0.544 \\
(6.356)\end{array}$ & \\
\hline $\operatorname{Div} v_{L S}^{M i g}$ & & & $\begin{array}{c}-0.006 \\
(0.018)\end{array}$ & & & $\begin{array}{c}8.248 \\
(11.028)\end{array}$ & & & $\begin{array}{c}10.354^{* *} \\
(4.464)\end{array}$ \\
\hline$M i g_{L S}$ & & & $\begin{array}{l}-0.022 \\
(0.019)\end{array}$ & & & $\begin{array}{c}-5.235 \\
(14.274)\end{array}$ & & & $\begin{array}{c}2.488 \\
(4.682)\end{array}$ \\
\hline $\ln (G D P p c)$ & $\begin{array}{c}0.040 \\
(0.026)\end{array}$ & $\begin{array}{c}0.040 \\
(0.029)\end{array}$ & $\begin{array}{c}0.038 \\
(0.026)\end{array}$ & $\begin{array}{l}42.394^{*} \\
(21.602)\end{array}$ & $\begin{array}{c}52.321^{* *} \\
(20.421)\end{array}$ & $\begin{array}{l}42.326^{*} \\
(21.372)\end{array}$ & $\begin{array}{c}8.637 \\
(7.281)\end{array}$ & $\begin{array}{l}10.891 \\
(7.248)\end{array}$ & $\begin{array}{c}8.543 \\
(7.322)\end{array}$ \\
\hline Observations & 200 & 200 & 200 & 200 & 200 & 200 & 200 & 200 & 200 \\
\hline Countries & 100 & 100 & 100 & 100 & 100 & 100 & 100 & 100 & 100 \\
\hline \multirow[t]{3}{*}{ Adj. R-Square } & 0.43 & 0.44 & 0.43 & 0.79 & 0.79 & 0.79 & 0.79 & 0.79 & 0.79 \\
\hline & \multicolumn{3}{|c|}{$H H I^{p}$} & \multicolumn{3}{|c|}{ products $^{p}$} & \multicolumn{3}{|c|}{ products $R C A^{p}$} \\
\hline & $(10)$ & (11) & $(12)$ & (13) & $(14)$ & $(15)$ & $(16)$ & $(17)$ & (18) \\
\hline \multicolumn{10}{|c|}{ Panel B - Ubiquity } \\
\hline$D i v_{A l l}^{M i g}$ & $\begin{array}{c}0.000 \\
(0.002)\end{array}$ & & & $\begin{array}{c}0.306 \\
(1.533)\end{array}$ & & & $\begin{array}{l}-0.025 \\
(0.801)\end{array}$ & & \\
\hline$M_{i g_{A l l}}$ & $\begin{array}{c}0.008^{* * *} \\
(0.002)\end{array}$ & & & $\begin{array}{c}-2.519^{*} \\
(1.358)\end{array}$ & & & $\begin{array}{c}-2.171^{* * *} \\
(0.693)\end{array}$ & & \\
\hline$D i v_{H S}^{M i g}$ & & $\begin{array}{c}0.002 \\
(0.002)\end{array}$ & & & $\begin{array}{c}1.567 \\
(1.418)\end{array}$ & & & $\begin{array}{c}-0.734 \\
(0.757)\end{array}$ & \\
\hline$M i g_{H S}$ & & $\begin{array}{c}0.008^{* * *} \\
(0.002)\end{array}$ & & & $\begin{array}{l}-2.017 \\
(2.029)\end{array}$ & & & $\begin{array}{c}-2.451^{* *} \\
(0.942)\end{array}$ & \\
\hline$D i v_{L S}^{M i g}$ & & & $\begin{array}{c}0.000 \\
(0.002)\end{array}$ & & & $\begin{array}{c}-0.063 \\
(1.512)\end{array}$ & & & $\begin{array}{c}0.020 \\
(0.798)\end{array}$ \\
\hline$M i g_{L S}$ & & & $\begin{array}{c}0.008^{* * *} \\
(0.001)\end{array}$ & & & $\begin{array}{l}-2.424^{*} \\
(1.341)\end{array}$ & & & $\begin{array}{c}-2.116^{* * *} \\
(0.663)\end{array}$ \\
\hline $\ln (G D P p c)$ & $\begin{array}{c}-0.014^{* * *} \\
(0.004)\end{array}$ & $\begin{array}{c}-0.013^{* * *} \\
(0.003)\end{array}$ & $\begin{array}{c}-0.013^{* * *} \\
(0.004)\end{array}$ & $\begin{array}{c}1.801 \\
(2.449)\end{array}$ & $\begin{array}{c}0.737 \\
(2.478)\end{array}$ & $\begin{array}{c}1.953 \\
(2.444)\end{array}$ & $\begin{array}{l}-1.398 \\
(1.586)\end{array}$ & $\begin{array}{l}-1.217 \\
(1.525)\end{array}$ & $\begin{array}{l}-1.449 \\
(1.578)\end{array}$ \\
\hline Observations & 200 & 200 & 200 & 200 & 200 & 200 & 200 & 200 & 200 \\
\hline Countries & 100 & 100 & 100 & 100 & 100 & 100 & 100 & 100 & 100 \\
\hline Adj. R-Square & 0.45 & 0.43 & 0.44 & 0.78 & 0.78 & 0.78 & 0.59 & 0.59 & 0.59 \\
\hline Controls & $\checkmark$ & $\checkmark$ & $\checkmark$ & $\checkmark$ & $\checkmark$ & $\checkmark$ & $\checkmark$ & $\checkmark$ & $\checkmark$ \\
\hline Regional FE & $\checkmark$ & $\checkmark$ & $\checkmark$ & $\checkmark$ & $\checkmark$ & $\checkmark$ & $\checkmark$ & $\checkmark$ & $\checkmark$ \\
\hline
\end{tabular}

Note: authors' calculations using data from [Hausmann et al. [2014), and Alesina et al. [2016). Standard errors are clustered at country level. $* \mathrm{p}<0.1,{ }^{* *} \mathrm{p}<0.05, * * * \mathrm{p}<0.01$. This table shows the effect of birthplace diversity on different measures of product diversification and ubiquity: Herfindahl-Hirschman Index on products exported (col. (1)-(3)), number of exported products (col. (4)-(6)), number of exported products with RCA $>1$ (col. (7)-(9)), weighted measures of countries product concentration (col. (10)-(12)), weighted sum of products uniqueness (col. (13)-(15)) and weighted sum of products with RCA bigger than one uniqueness (col. (16)-(18)). 
measures as dependent variables. The top panel presents the results for the diversification measures, while the bottom panel presents the estimates for the ubiquity measures. Panel A shows that across most specifications, birthplace diversity is associated with higher diversification (again, note that the point estimates are negative when the dependent variable is a concentration index and positive when using number of products). While not all point estimates are statistically different from zero based on the conventional confidence intervals, we do find significant coefficients for the number of products with RCA above one (columns 7 to 9) ${ }^{22}$ For instance, an increase of one standard deviation in our birthplace diversity index is associated with an increase in the number of goods exported competitively by around 12 (roughly a 10 percent increase, based on the sample mean of about 120, with standard deviation equal to 81) ${ }_{23}^{23}$ Panel B shows the partial correlations between skill-specific migration diversity and export ubiquity. Overall the estimates are not statistically different from zero, however the direction of the point estimates is toward a reduction of products ubiquity ${ }^{24}$

All in all, our evidence points to birthplace diversity explaining higher levels of complexity, in part, through the diversification of country's export basket, though the evidence is not very robust across diversification measures.

\section{Conclusion}

We investigate the relationship between birthplace diversity and economic complexity. Throughout all of our estimations, which include the use of instrumental variables to reduce endogeneity concerns, we find indeed a strong relationship between the two. In particular, our main finding is that increasing birthplace diversity by one standard deviation is associated with an increase in economic complexity of 0.10 to 0.18 standard deviations, depending on the specification. This holds particularly true for diversity among collegeeducated migrants and for countries at intermediate levels of economic complexity. We further find that the positive relationship between diversity and complexity is mostly driven by diversity due to immigrants coming from more countries of origin (as opposed to changes in the composition of birthplaces from the same set of countries that could also increase diversity). Finally, we also show that the results are driven by the diversification component of the economic complexity index rather than by its uniqueness component.

All this suggests that our results are driven by skill complementarities: immigrants from different places bring in new and different skills that result in the ability of a country to have a more diverse export basket, resulting in higher economic complexity.

\footnotetext{
${ }^{22}$ Removing from the set of controls measures of imports and exports diversity does not significantly affect the size and precision of the estimates.

${ }^{23}$ Table D-III presents the results for alternative diversification measures. The direction of the results is similar, and we find significant coefficients associated with the Gini index. From the estimates, an increase of one standard deviation in birthplace diversity is associated with a drop of the Gini coefficient by around 0.012 (roughly 1.3 percent based on a sample mean equal to $0.93)$.

${ }^{24}$ Table D-II in the Online Appendix proposes an alternative way to test the effect of diversity on products ubiquity. Using countries averages of Product Complexity Index over the top 3, 5 and 10 products in terms of exports, we test whether the best products export become more unique. The Product Complexity Index - an index that mirrors the ECI - measures how much a given product is complex: higher values imply products that are exported by fewer countries and that those countries are highly diversified. Even though the direction of the estimates indicates higher uniqueness, the estimates are not statistically different from zero.
} 
Considering the full set of results, we conclude that immigration diversity is an important building block of economic complexity, and thus of economic growth. Our results are yet another piece of evidence pointing to immigration as a key input in the process of structural transformation and economic development. 


\section{References}

Ager, P., and Brückner, M. (2013). Cultural diversity and economic growth: Evidence from the US during the age of mass migration. European Economic Review, 64: 76-97.

Alesina, A., Devleeschauwer, A., Easterly, W., Kurlat, S., \& Wacziarg, R. (2003). Fractionalization. Journal of Economic Growth, 8(2): 155-194.

Alesina, A., \& La Ferrara, E. (2005). Ethnic diversity and economic performance. Journal of economic literature, 43(3): 762-800.

Alesina, A., Harnoss, J. and Rapoport, H. (2016). Birthplace diversity and economic prosperity. Journal of Economic Growth, 21: 101-138.

Alesina, A., Murard, E., and Rapoport, H. (2019). Immigration and Preferences for Redistribution in Europe CEPR Discussion Paper No. 14211, December

Angrist, J., and Pischke, J. S. (2009). Mostly harmless econometrics: an empiricists guide. Princeton University Press (392 p.).

Ashraf, Q., \& Galor, O. (2013). The 'Out of Africa' hypothesis, human genetic diversity, and comparative economic development. American Economic Review 103(1): 1-46.

Artuc, E., Docquier, F., Özden, C., and Parsons, C. (2015). A Global Assessment of Human Capital Mobility: The Role of Non-OECD Destinations. World Development, 65: 6-26.

Bahar, D., Hauptmann, A., Özgüzel, C., and Rapoport, H. (2019). Migration and Post Conflict Reconstruction: the Effect of Returning Refugees on Export Performance in the Former Yugoslavia. IZA DP No. 12412, June

Bahar, D., and Rapoport, H. (2018). Migration, knowledge diffusion and the comparative advantage of nations. The Economic Journal, 128(612): F273-F305.

Bahar, D., and Santos, M. A. (2018). One more resource curse: Dutch disease and export concentration. Journal of Development Economics, 132: 102-114.

Bahar, D., Choudhury, P., \& Rapoport, H. (2020). Migrant Inventors and the Technological Advantage of Nations. Research Policy, forthcoming

Balassa, B. (1965). Trade liberalisation and "revealed" comparative advantage. The Manchester School, 33(2): 99-123.

Barro, R., and Lee, J. (2013). A new data set of educational attainment in the world, 1950-2010. Journal of Development Economics, 104: 184-198. 
Böheim, R., Horvath, T., and Mayr, K. (2012). Birthplace diversity of the workforce and productivity spill-overs in firms. WIFO Working Papers No. 438.

Borjas, G. J. (2019). Immigration and Economic Growth. National Bureau of Economic Research. WP No. w25836.

Bove, V., \& Elia, L. (2016). Migration, diversity, and economic growth. World Development, 89: 227-239.

Broekel, T. (2019). Using structural diversity to measure the complexity of technologies. PloS one, 14(5).

Cadot, O., Carrère, C., and Strauss-Kahn, V. (2011). Export diversification: What's behind the hump? Review of Economics and Statistics, 93(2): 590-605.

Cadot, O., Carrere, C., \& Strauss-Kahn, V. (2013). Trade diversification, income, and growth: what do we know?. Journal of Economic Surveys, 27(4): 790-812.

Card, D. (2001). Immigration Inflows, Native Outflows and the Local Labor Market Impacts of Higher Immigration. Journal of Labor Economics 19: 22-64.

Desmet, K., Ortuño-Ortín, I., \& Wacziarg, R. (2012). The political economy of linguistic cleavages. Journal of development Economics, 97(2): 322-338.

Docquier, F., Machado, J., and Sekkat, K. (2015). Efficiency gains from liberalizing labor mobility. The Scandinavian Journal of Economics, 117(2): 303-346.

Docquier, F., Lodigiani, E., Rapoport, H., and Schiff, M. (2016). Emigration and Democracy. Journal of Development Economics, 120: 209-223.

Docquier, F., Turati, R., Valette, J. and Chrysovalantis, V. (2019). Birthplace diversity and Economic Growth: Evidence from the US States in the Post-World War II Period. Journal of Economic Geography forthcoming.

Felipe, J., Kumar, U., Abdon, A., \& Bacate, M. (2012). Product complexity and economic development. Structural Change and Economic Dynamics, 23(1): 36-68.

Feenstra, R. C., Lipsey, R. E., Deng, H., Ma, A. C., \& Mo, H. (2005). World trade flows: 1962-2000. National Bureau of Economic Research WP No. w11040.

Feenstra, R. C., Inklaar, R. \& Timmer, M. P. (2015). The Next Generation of the Penn World Table. American Economic Review 105(10): 3150-3182.

Fulford, S., Petkov, I., and Schiantarelli, F. (2017). Does it matter where you came from? Ancestry composition and economic performance of U.S. counties, 1850-2010. Boston College Working Papers in Economics No. 875 . 
Goldsmith-Pinkham, P., Sorkin, I., and Swift, H. (2020). Bartik Instruments: What, When, Why, and How. American Economic Review, forthcoming.

Hausmann, R., and Klinger, B. (2007). The structure of the product space and the evolution of comparative advantage. Center for International Development at Harvard University, WP No. 146

Hausmann, R., and Hidalgo, C. A. (2011). The network structure of economic output. Journal of Economic Growth, 16(4): 309-342.

Hausmann, R., Hidalgo, C. A., Bustos, S., Coscia, M., Simoes, A., and Yildirim, M. A. (2014). The atlas of economic complexity: Mapping paths to prosperity. Mit Press.

Head, K., Mayer, T., \& Ries, J. (2010). The erosion of colonial trade linkages after independence. Journal of International Economics, 81(1), 1-14.

Hidalgo, C. A., Klinger, B., Barabási, A. L., and Hausmann, R. (2007). The product space conditions the development of nations. Science, 317(5837): 482-487.

Hidalgo, C. A., and Hausmann, R. (2009). The building blocks of economic complexity. Proceedings of the national academy of sciences, 106(26): 10570-10575.

Hjort, J. (2014). Ethnic divisions and production in firms. Quarterly Journal of Economics, 129(4): 18991946.

Imbs, J., and Wacziarg, R. (2003). Stages of diversification. American Economic Review, 93(1): 63-86.

Jaeger, D. A., Ruist, J., and Stuhler, J. (2018). Shift-share instruments and the impact of immigration. National Bureau of Economic Research. WP No. w24285.

Javorcik, B. S., Lo Turco, A., \& Maggioni, D. (2018). New and improved: Does FDI boost production complexity in host countries?. The Economic Journal, 128(614): 2507-2537.

Lyons, E. (2017). Team production in international labor markets: Experimental evidence from the field. American Economic Journal: Applied Economics, 9(3): 70-104.

Marshall, M. G., Gurr, T. R., \& Jaggers, K. (2013). Polity IV project: Political regime characteristics and transitions, 1800-2012. Center for Systemic Peace.

Montalvo, J. G., \& Reynal-Querol, M. (2005). Ethnic polarization, potential conflict, and civil wars. American economic review, 95(3): 796-816.

Moriconi, S., Peri, G., and Turati, R. (2018). Skill of the Immigrants and Vote of the Natives: Immigration and Nationalism in European Elections 2007-2016. National Bureau of Economic Research. WP No. w25077. 
Ortega, F., and Peri, G. (2014). Openness and income: The roles of trade and migration. Journal of International Economics, 92(2): 231-251.

Ottaviano, G. I., and Peri, G. (2006). The economic value of cultural diversity: evidence from US cities. Journal of Economic geography, 6(1): 9-44.

Özden, Ç., Parsons, C. R., Schiff, M., and Walmsley, T. L. (2011). Where on earth is everybody? The evolution of global bilateral migration 1960-2000. The World Bank Economic Review, 25(1): 12-56.

Ozgen, C., Peters, C., Niebuhr, A., Nijkamp, P. and Poot, J. (2014). Does cultural diversity of migrants employees affect innovation? International Migration Review, 48(9): 377-416.

Parrotta, P., Pozzoli, D., and Pytlikova, M. (2014). Does labor diversity affect firm productivity? European Economic Review, 66: 144-179.

Silva, J. S., and Tenreyro, S. (2006). The log of gravity. The Review of Economics and statistics, 88(4): 641-658.

Spilimbergo, A. (2009). Democracy and foreign education. American economic review, 99(1): 528-43.

Solow, R. M. (1956). A contribution to the theory of economic growth. The Quarterly Journal of Economics, 70(1): 65-94.

Stock, J. H., and Yogo, M. (2002). Testing for weak instruments in linear IV regression. National Bureau of Economic Research. Technical Working Paper No. 284

Trax, M., Brunow, S., and Suedekum, J. (2015). Cultural diversity and plant-level productivity. Regional Science and Urban Economics, 53: 85-96

U.N. Population Division. (2013). World population prospects: The 2013 revision. Retrieved from, http://

Valette, J. (2018). Do migrants transfer productive knowledge back to their origin countries? The Journal of Development Studies, 54(9): 1637-1656.

World Bank Group (2013). World development indicators 2013. World Bank Publications, 2013. 


\section{Appendix A Harmonization of DIOC and ADOP data}

To minimize the potential bias due to omitted variable, we combined data of DIOC (Database on Immigrants in OECD counties) (http://www.oecd.org/els/mig/dioc.htm) and ADOP (2015) data (https://perso. uclouvain.be/frederic.docquier/filePDF/ADOP_AgeOfEntry.xlsx), to have a panel of 22 destination countries over the period 1990 to 2010. Since DIOC is available over 2000 and 2010 while ADOP is available over 1990 and 2000, we had to harmonize our data sources. Moreover we take DIOC data as main reference in order to harmonize ADOP 1990 data with the rest of DIOC data. Our harmonization process took the following steps:

1. we compute the bilateral skill specific weight in the year 2000, such that ADOP data should be equal to DIOC, namely: $M I G_{s, 2000}^{D I O C}=M I G_{s, 2000}^{A D O P} * w_{s, 2000}$

2. we re-weight the $1990 \mathrm{ADOP}$ bilateral stocks using the weights for the 2000 , namely $M I G_{s, 1990}^{A D O P_{w}}=$ $M I G_{s, 1990}^{A D O P} * w_{s, 2000}$

3. for bilateral stocks where we could not compute the weight due to missing values or zeroes, we compute the bilateral skill specific growth rate between 2000 and 2010 with DIOC and we assume a constant linear trend also for 1990. If we define $g_{s, 00}$ the bilateral skill specific growth rate, then we can compute the missing bilateral skill migration stocks in the 1990 as follow: $M I G_{s, 1990}^{A D O P_{w}}=M I G_{s, 2000}^{D I O C} /\left(1+g_{s, 00}\right)$.

After this procedure we have a panel of 25 destination countries with 194 origin countries. However, due to missing information in the 1990 for Luxembourg, Czech Republic and Slovak Republic on our ECI data, our final panel will be on 22 destination countries. 


\section{Appendix B Additional Tables}

Table B-1: Correlates across different measures of Diversity

\begin{tabular}{|c|c|c|c|c|}
\hline Diversity Measures & $\begin{array}{c}(1) \\
D i v_{H S}^{M i g} \\
\end{array}$ & $\begin{array}{c}(2) \\
M i g_{H S} \\
\end{array}$ & $\begin{array}{c}(3) \\
D i v_{L S}^{M i g} \\
\end{array}$ & $\begin{array}{c}(4) \\
M i g_{L S} \\
\end{array}$ \\
\hline N\#Origin & $0.263^{* * *}$ & $0.293^{* * *}$ & $0.264^{* * *}$ & $0.341^{* * *}$ \\
\hline $\mathrm{Pol}_{H S}^{\mathrm{Mig}}$ & $-0.386^{* * *}$ & -0.0845 & $-0.343^{* * *}$ & $-0.173^{*}$ \\
\hline $\operatorname{Pol}_{L S}^{\mathrm{Mig}}$ & 0.0269 & $-0.181^{*}$ & $-0.160^{*}$ & $-0.144^{*}$ \\
\hline Theil & $-0.901 * * *$ & -0.118 & $-0.775^{* * *}$ & $-0.177^{*}$ \\
\hline Theil $_{L S}^{M i g}$ & $-0.761^{* * *}$ & $-0.217^{* *}$ & $-0.911^{* * *}$ & $-0.180^{*}$ \\
\hline Theil $_{H S}^{W, M i g}$ & $-0.639^{* * *}$ & 0.125 & $-0.567^{* * *}$ & 0.116 \\
\hline Theil $_{L S}^{W, M i g}$ & $-0.465^{* * *}$ & 0.0119 & $-0.646^{* * *}$ & 0.0979 \\
\hline Theil $_{H S}^{B, M i g}$ & $-0.234^{* * *}$ & $-0.235^{* * *}$ & $-0.184^{* *}$ & $-0.281^{* * *}$ \\
\hline Theil $_{L S}^{B, M i g}$ & $-0.254^{* * *}$ & $-0.229^{* *}$ & $-0.208^{* *}$ & $-0.285^{* * *}$ \\
\hline
\end{tabular}


Table B-2: OLS regression on Economic Complexity Index - Different Diversity Indexes

\begin{tabular}{|c|c|c|c|c|c|c|}
\hline $\begin{array}{l}\text { Dep. Variable: } \\
E C I\end{array}$ & $\begin{array}{l}(1) \\
\text { OLS }\end{array}$ & $\begin{array}{l}(2) \\
\text { OLS }\end{array}$ & $\begin{array}{c}(3) \\
\text { OLS }\end{array}$ & $\begin{array}{l}(4) \\
\text { OLS }\end{array}$ & $\begin{array}{c}(5) \\
\text { OLS }\end{array}$ & $\begin{array}{c}(6) \\
\text { OLS }\end{array}$ \\
\hline Sample: & \multicolumn{6}{|c|}{$2^{\text {nd }}$ Tercile } \\
\hline Diversity Measures & $D i v^{M i g}$ & $D i v^{M i g}$ & $\mathrm{Pol}^{\mathrm{Mig}}$ & Theil ${ }^{M i g}$ & Theil $^{W, M i g}$ & Theil $^{B, M i g}$ \\
\hline$H S$ Index & $\begin{array}{c}0.128^{* *} \\
(0.058)\end{array}$ & $\begin{array}{c}0.127^{* *} \\
(0.059)\end{array}$ & $\begin{array}{l}-0.042 \\
(0.054)\end{array}$ & $\begin{array}{c}-0.142^{*} \\
(0.072)\end{array}$ & $\begin{array}{l}-0.107 \\
(0.074)\end{array}$ & $\begin{array}{c}-0.283^{* *} \\
(0.123)\end{array}$ \\
\hline$L S$ Index & $\begin{array}{c}0.024 \\
(0.087)\end{array}$ & $\begin{array}{c}0.025 \\
(0.088)\end{array}$ & $\begin{array}{l}0.092 \\
(0.054)\end{array}$ & $\begin{array}{l}0.055 \\
(0.077)\end{array}$ & $\begin{array}{l}0.085 \\
(0.079)\end{array}$ & $\begin{array}{l}0.256^{*} \\
(0.135)\end{array}$ \\
\hline $\mathrm{Mig}_{H S}$ & $\begin{array}{l}-0.072 \\
(0.085)\end{array}$ & $\begin{array}{l}-0.072 \\
(0.085)\end{array}$ & $\begin{array}{l}-0.048 \\
(0.071)\end{array}$ & $\begin{array}{l}-0.064 \\
(0.094)\end{array}$ & $\begin{array}{l}-0.073 \\
(0.084)\end{array}$ & $\begin{array}{l}-0.056 \\
(0.097)\end{array}$ \\
\hline$M i g_{L S}$ & $\begin{array}{c}0.090 \\
(0.098)\end{array}$ & $\begin{array}{c}0.088 \\
(0.099)\end{array}$ & $\begin{array}{l}0.105 \\
(0.094)\end{array}$ & $\begin{array}{c}0.086 \\
(0.110)\end{array}$ & $\begin{array}{c}0.112 \\
(0.111)\end{array}$ & $\begin{array}{c}0.078 \\
(0.115)\end{array}$ \\
\hline N\#Origin & & $\begin{array}{c}0.000 \\
(0.001)\end{array}$ & & & & \\
\hline Observations & 67 & 67 & 67 & 67 & 67 & 67 \\
\hline Countries & 44 & 44 & 44 & 44 & 44 & 44 \\
\hline Adj. R-Square & 0.34 & 0.37 & 0.21 & 0.24 & 0.15 & 0.19 \\
\hline Controls & $\checkmark$ & $\checkmark$ & $\checkmark$ & $\checkmark$ & $\checkmark$ & $\checkmark$ \\
\hline Regional FE & $\checkmark$ & $\checkmark$ & $\checkmark$ & $\checkmark$ & $\checkmark$ & $\checkmark$ \\
\hline $\begin{array}{l}\text { Note: authors' calc } \\
\text { Standard errors are clu } \\
\text { variable is a standardiz } \\
\text { full set of controls of } \\
\text { of countries is compose } \\
\text { column shows different } \\
\text { fractionalization index } \\
\text { origin (col. 2), polariza } \\
\text { component (col. 5) and }\end{array}$ & $\begin{array}{l}\text { ulations u } \\
\text { stered at } \\
\text { d measur } \\
\text { 'able } 3 \text { of } \\
\text { d by cou } \\
\text { approach } \\
\text { (col. 1), } \\
\text { tion inde } \\
\text { between }\end{array}$ & $\begin{array}{l}\text { ing data fr } \\
\text { ountry lev } \\
\text { of the Eco } \\
\text { llesina } e t \\
\text { ries belong } \\
\text { to measul } \\
\text { actionaliza } \\
\text { (col. 3), t } \\
\text { mponent }\end{array}$ & $\begin{array}{l}\text { mausm } \\
\text { l. }{ }^{*} \mathrm{p}<0 \text {. } \\
\text { omic Con } \\
\text { ll. }(2016) \\
\text { ing to the } \\
\text { e skill-spec } \\
\text { tion index } \\
\text { eil index } \\
\text { col. } 6) \text {. }\end{array}$ & $\begin{array}{l}\text { ann et al. } \\
1, * * \mathrm{p}<0.0 \\
\text { plexity Ind } \\
\text { lus the log } \\
2^{\text {nd }} \text { tercile } \\
\text { ific birthple } \\
\text { plus the } \mathrm{n} \\
\text { (col. 4) an }\end{array}$ & $\begin{array}{l}\text { (4) and Alesin } \\
* * * \text { p }<0.01 . \\
\text { Each regressi } \\
\text { thm of GDP. } \\
\text { the ECI dist } \\
\text { diversity amo } \\
\text { ber of migran } \\
\text { is decompositi }\end{array}$ & $\begin{array}{l}\text { a et al. }(2016) \text {. } \\
\text { The dependent } \\
\text { on includes the } \\
\text { The sample of } \\
\text { cibution. Each } \\
\text { ng immigrants: } \\
\text { ts' countries of } \\
\text { on: the within }\end{array}$ \\
\hline
\end{tabular}


Table B-3: OLS regression on Economic Complexity Index Origin Specific Effect

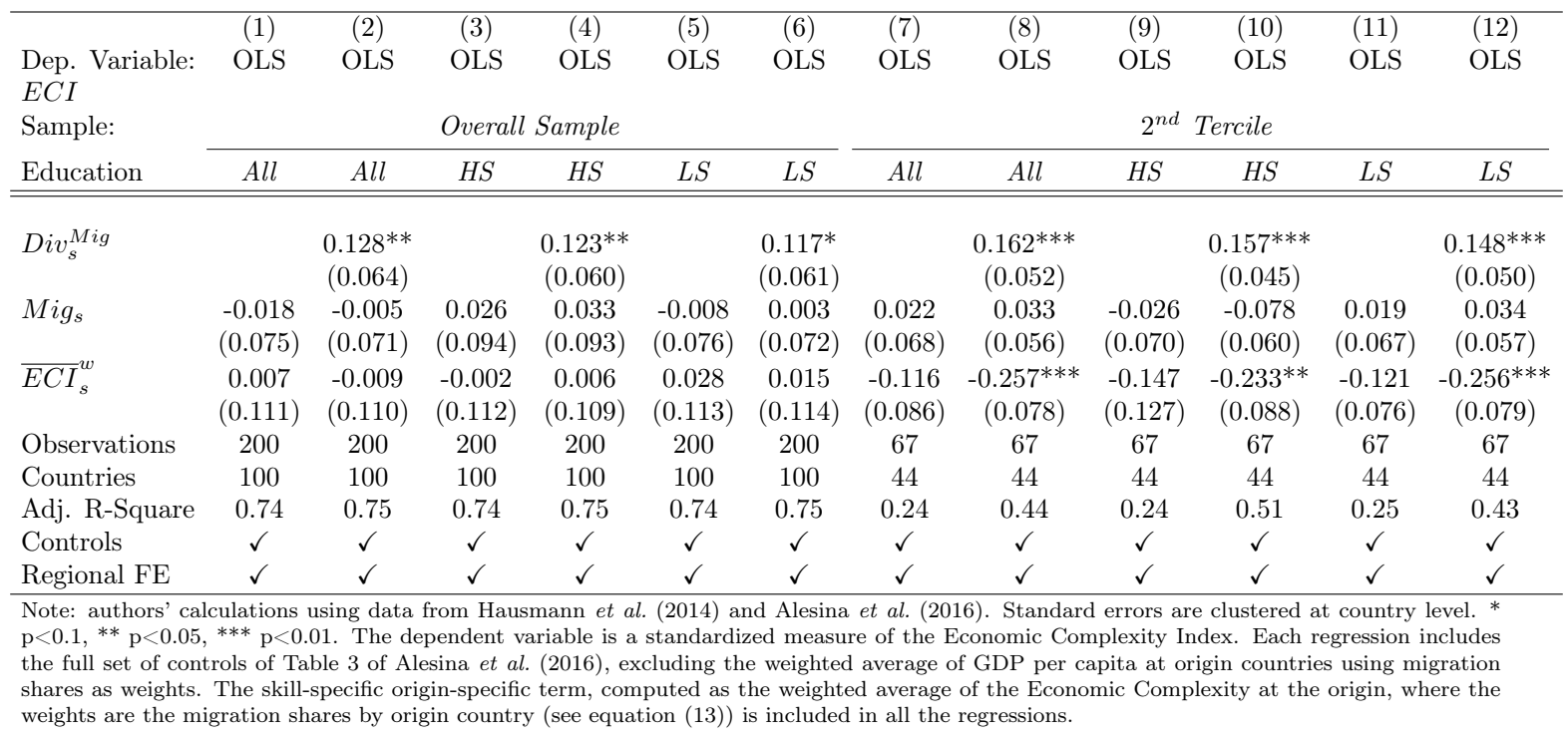

Table B-4: OLS regression on Economic Complexity Index Robustness by previous level of diversity

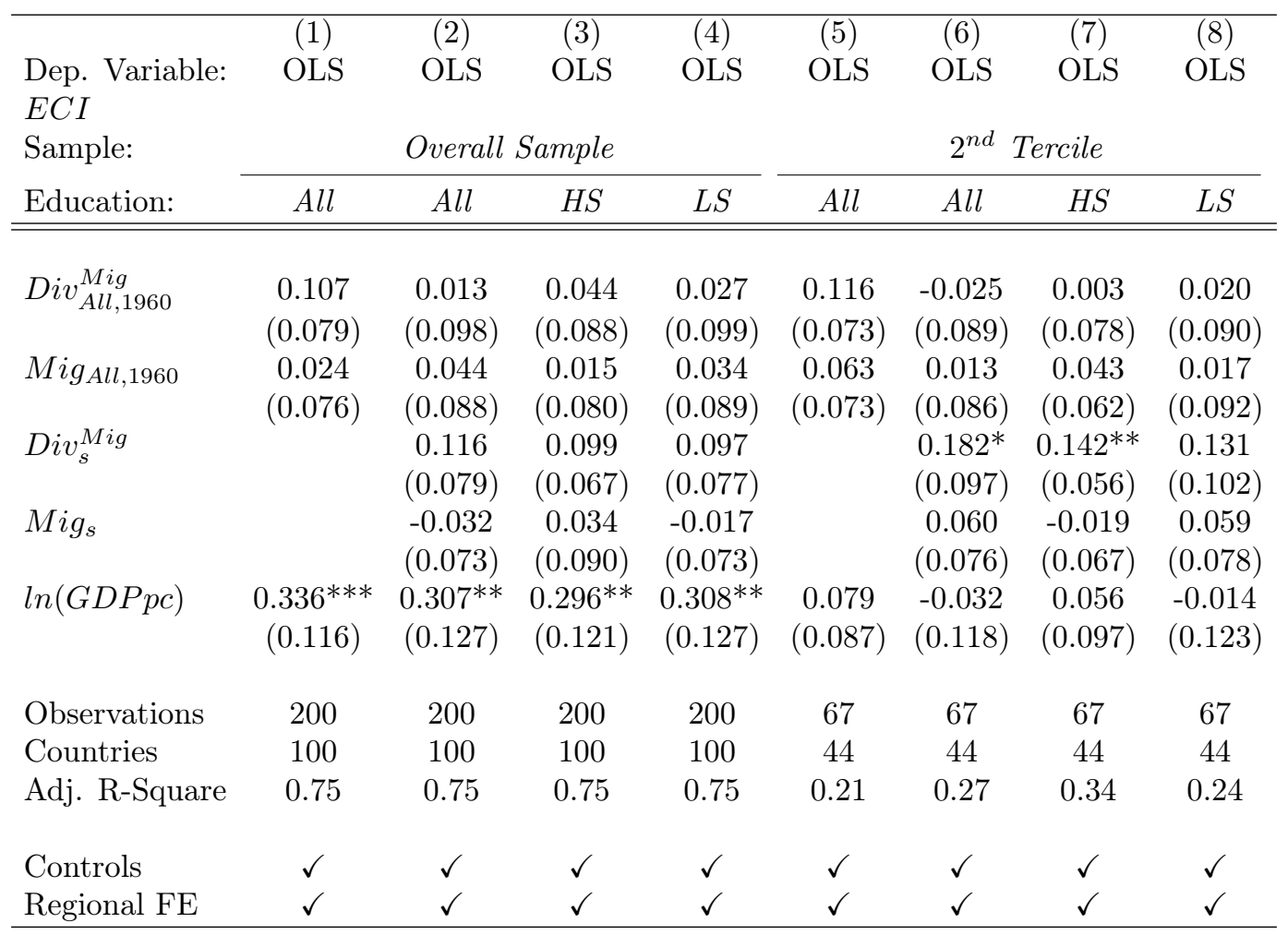

Note: authors' calculations using data from Hausmann et al. (2014) and Alesina et al. (2016). Standard errors are clustered at country level. ${ }^{*} \mathrm{p}<0.1,{ }^{* *} \mathrm{p}<0.05,{ }^{* * *} \mathrm{p}<0.01$. The dependent variable is a standardized measure of the Economic Complexity Index. Each regression includes the full set of controls of Table 3 of Alesina et al. (2016). 